\title{
TWO NEW SPOTTED CHILOSCHISTA SPECIES (ORCHIDACEAE: AERIDINAE) FROM BHUTAN
}

\author{
Nima Gyeltshen ${ }^{1}$, Choki Gyeltshen ${ }^{1}$, Kezang Tobgay ${ }^{1}$, Stig Dalström ${ }^{1-3,7}$, \\ Dhan Bdr. Gurung ${ }^{4}$, Ngawang Gyeltshen ${ }^{5} \&$ Bhakta Bdr. Ghalley ${ }^{6}$ \\ ${ }^{1}$ National Biodiversity Centre, Ministry of Agriculture and Forests, Royal Government of Bhutan, \\ Serbithang, Thimphu 11001, Bhutan \\ 22304 Ringling Boulevard, unit 119, Sarasota FL 34237, U.S.A. \\ ${ }^{3}$ Lankester Botanical Garden, University of Costa Rica, Cartago, Costa Rica \\ ${ }^{4}$ Associate Professor, College of Natural Resources, Lobesa, Royal University of Bhutan \\ ${ }^{5}$ Senior Forestry Officer, Biodiversity Inventory Program, Wildlife Conservation Division, Department \\ of Forests and Park Services, Ministry of Agriculture and Forests, Royal Government of Bhutan, \\ Thimphu, Bhutan
}

${ }^{6}$ Forest Ranger 1, Jigme Khesar Strict Nature Reserve, Department of Forests and Park Services, Ministry of Agriculture and Forests, Royal Government of Bhutan, Haa, Bhutan

${ }^{7}$ Corresponding author: stigdalstrom@gmail.com

\begin{abstract}
Two new spotted species of Chiloschista from Bhutan are described, illustrated, and compared with similar species. The second of the new species has been misidentified in previous publications as C. lunifera and C. parishii, and a comparison between the three is provided. It is also compared with $C$. glandulosa, which is a distinctly smaller-flowered species from the coastal area of southwestern India, and with $C$. javanica from Indonesia. The latter species and $C$. parishii are easily distinguished from both new species by having hairs on the backside and along the margins of the sepals and petals, as opposed to having virtually glabrous to indistinctly micro-pubescent sepals and petals for the new species. Although many spotted Chiloschista species are superficially similar, the differences can be better observed when studying the internal morphology of particularly the glandular callosity in the saccate lip. The morphological differences are often minute and difficult to describe in words, but are more easily recognized when compared with illustrations and photographs.
\end{abstract}

Key Words: Chiloschista glandulosa, C. javanica, C. lunifera, C. parishii, new Chiloschista

Introduction. In 2009, work began by the staff at the National Biodiversity Centre (NBC), an independent branch of the Ministry of Agriculture and Forests in Bhutan, to survey the orchid flora in the country with the assistance of Stig Dalström of Sarasota, Florida, and Thomas Höijer of Jakobsberg, Sweden. At the time, there were three different publications available for the identification of Bhutanese orchids: The Orchids of Bhutan (Pearce \& Cribb 2002), An illustrated guide to the orchids of Bhutan (Gurung 2006), and The Field Guide to the orchids of Bhutan (Dorji 2008). These important publications have been immensely useful and made it possible to advance rapidly with the listing of identified orchid species.
Every now and then the members of the "orchid team" have run into some disagreements, however, concerning the identification of some of the published orchids. This, in turn, has forced the members to delve into some complicated taxonomic issues that could only be solved by careful analysis of freshly collected plant material and comparisons with information from preserved type specimens, older publications, and protologues. In some cases, this research has led the team to revise the identification of certain species, and one such case concerns the genus Chiloschista Lindl.

The first species to be included in this genus was Epidendrum usneoides D.Don. It was described and published by David Don in Prodromus Florae 


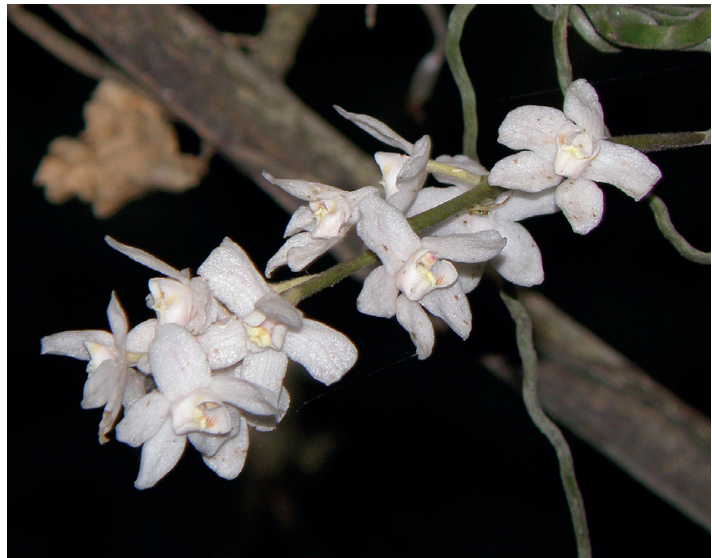

FIgURE 1. Chiloschista usneoides in the natural habitat near Jangbi, Trongsa district. Photo by Stig Dalström.

Nepalensis (1825), a publication based primarily on Nathaniel Wallich's and others' plant collections from Nepal. This species was collected "in 1818 in many diff. places of Nepal" (Reichenbach 1863). John Lindley then transferred this species to his newly created genus Chiloschista in Edwards's Botanical Register (Lindley 1832). It has remained there until today, aside from a temporary detour through Sarcochilus R.Br. (Reichenbach 1863), and Thrixspermum Lour (Reichenbach 1867). This species was originally described by Don as having rose-colored flowers, although most commonly the petite and attractive flowers are clear white, with or without a rose hue on the sepals. Chiloschista usneoides (D.Don) Lindl., is fairly common in Bhutan and flowers in April (Fig. 1-2). Nicholas Pearce and Phillip Cribb (2002) listed C. parishii Seidenf., as a second and only other Chiloschista species from Bhutan. It is described as having yellow sepals and petals with large brown spots and blotches. As it turns out, this particular color description fits many currently accepted species in the genus, which has caused some taxonomic confusion. Here, we attempt to clarify this. The listing of the Bhutanese " $C$. parishii" appears to be based on Gunnar Seidenfaden's identification of Bhutanese and Himalayan material cited by him in his treatment of Chiloschista in Thailand (Seidenfaden 1988). This is also where Chiloschista parishii is scientifically described by him based on a flowerless specimen and a colored drawing assembled on April 14, 1859, by Reverend Charles Samuel Pollock Parish

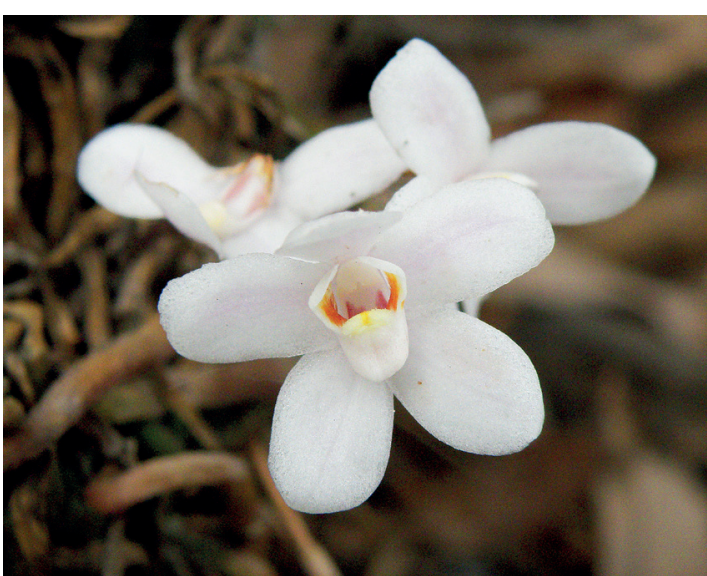

FiguRE 2. Chiloschista usneoides close-up of the attractive flowers. Photo by Stig Dalström.

(\#55), and currently deposited in the herbarium at the Museum of Natural History in Vienna, Austria (sheets $11583,26237)$. This original collection is apparently from the Moulmein (today spelled Mawlamyine) area of Myanmar (Seidenfaden 1988). The distribution for this species is listed by Seidenfaden as not only Myanmar and Thailand but also includes Nepal and Bhutan as well as a large area of the Himalayan region of India. The illustration that accompanies the type description of $C$. parishii is based on a specimen from Doi Saket in northern Thailand (GT7403, C), however, which correlates very well with Parish's drawing of his original plant (Seidenfaden 1988). During a visit to the western part of Thailand in 2009, SD was able to make a detailed drawing of a flower that agrees well with the description and illustration of $C$. parishii (Fig. 3 ). The plant from which this drawing was made (Fig. 4) originated in the area along the border between Thailand and Myanmar and not far from "Moulmein", "as the crow flies". At that point, a solid understanding of what the real Chiloschista parishii looks like was established.

Resulting from recent extensive explorations in various parts of Bhutan by several combinations of the NBC orchid team, with occasional participation by Forest Rangers and others, not one but three spotted Chiloschista species were found (Fig. 5). And despite the similar color patterns, none of these fit the morphological description of the real Chiloschista parishii, or any other previously described Chiloschista for that matter. The first of these species to be described 

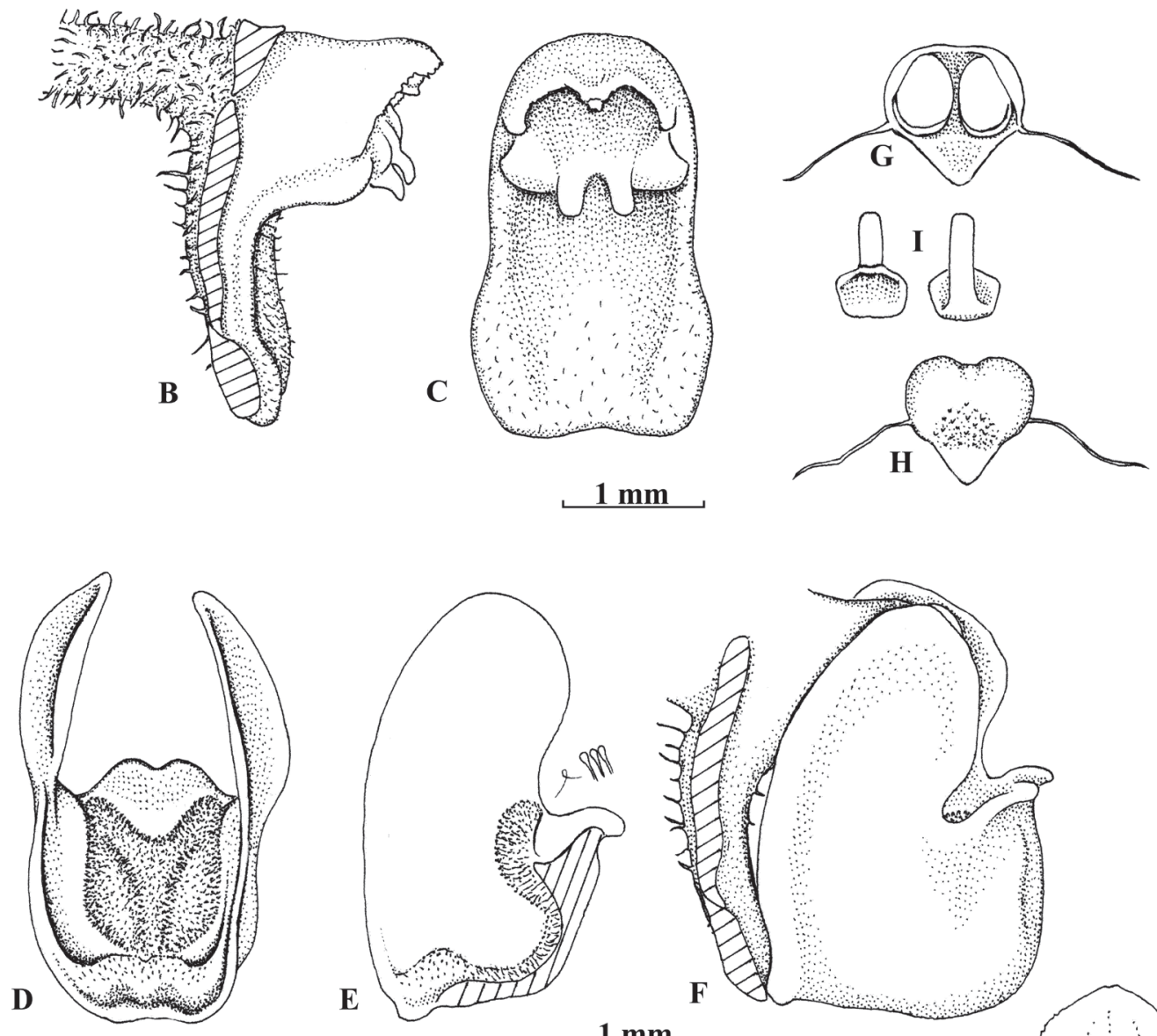

E
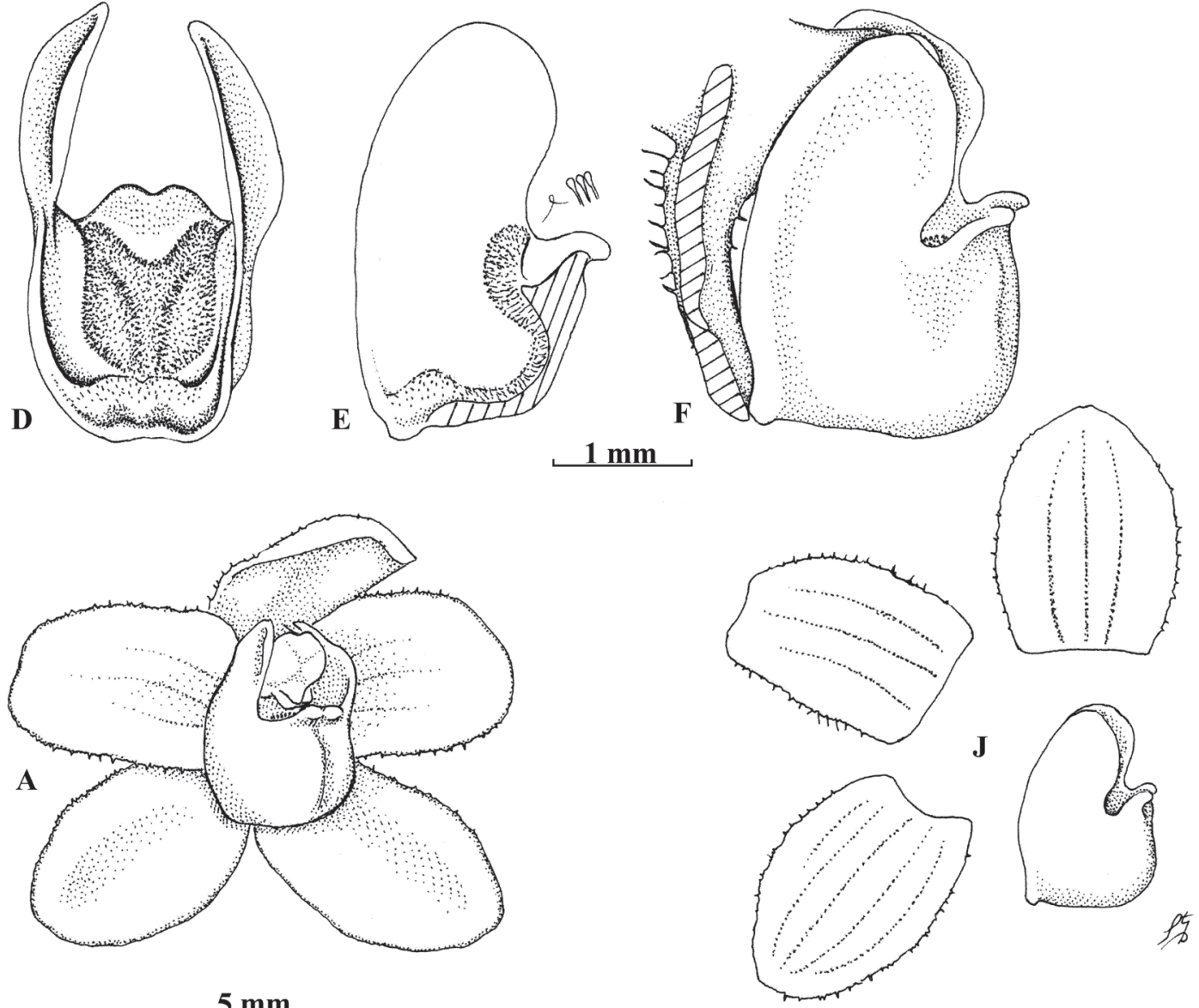

$5 \mathrm{~mm}$

Figure 3. Chiloschista parishii Seidenf. A. Flower, front angled view. B. Column, lateral view. C. Column, ventral view. D. Lip, back (internal) view. E. Lip cleft, lateral view. F. Column and lip, lateral view. G. Anther cap with pollinia, ventral view. H. Anther cap, dorsal view. I. Stipe and viscidium, back and front view. J. Dissected flower. Drawn from S. Dalström 3023 (Dalström archives) by Stig Dalström. 


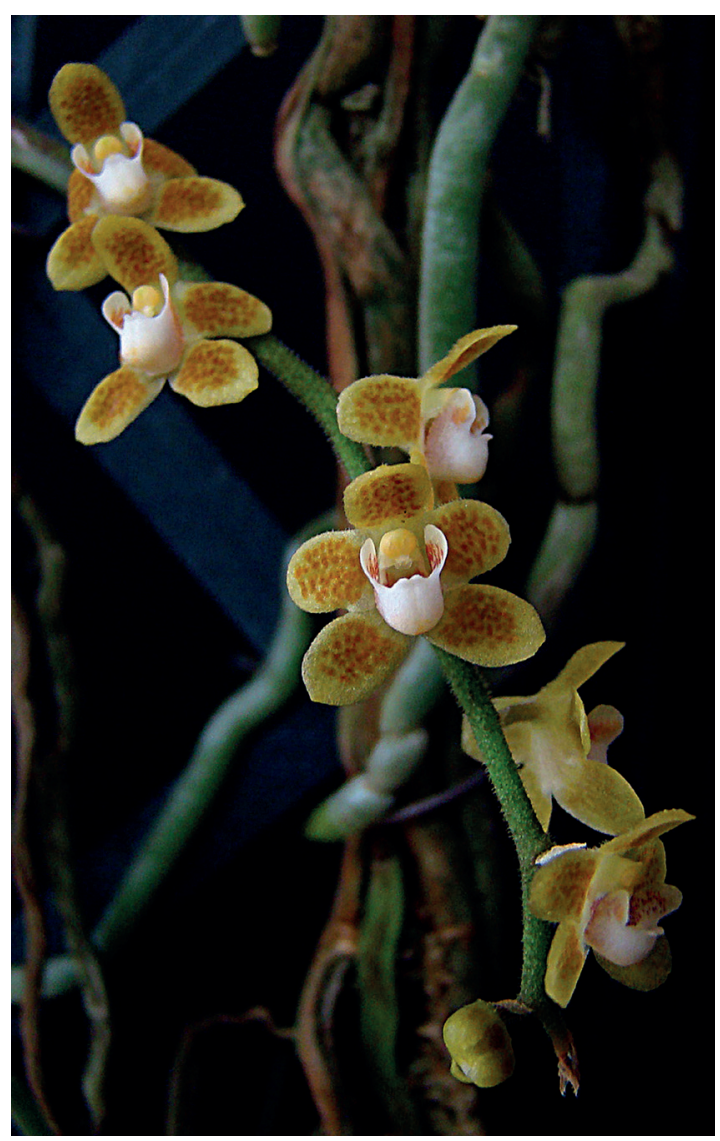

FIgURE 4. Chiloschista parishii, plant from western Thailand that correlates with the type of this species ( $S$. Dalström 3023). Photo by Stig Dalström. as new to science was C. gelephuense C.Gyeltshen \& Dalström (Gyeltshen et al. 2019) (Fig. 5-6). The second species, which is the first to be described here, has so far only been found along the Mangde Chhu river in the Trongsa and Zhemgang districts and has not previously appeared in any publication known to us. It is quite distinct in its glandular sub-triangular lip callus and with an unusually dense inflorescence (Fig. 7-8). The third spotted species from Bhutan, which is the second to be described here (Fig. 9-10), is a bit more complicated to handle taxonomically and it has a long and involved history. It appeared for the first time with an illustration in Curtis's Botanical Magazine (Hooker 1889), as Sarcochilus lunifer (Rchb.f.) Benth. ex Hook.f. ("luniferus") (Fig. 11). In the accompanying text by Joseph Dalton Hooker, it is mentioned that this species was originally described as Thrixspermum luniferum Rchb.f. (Reichenbach 1868) but that George Bentham (1883) rejected the genus Thrixspermum because its description was incomplete and "the name was utterly bad in construction". It was therefore transferred to Sarcochilus (Hooker 1889). The illustrated plant was sent by George King from the Royal Botanical Gardens in Calcutta in 1887 and flowered the following year (Hooker 1889). The species is mentioned as coming from "Burma" in the heading of the plate, thus referring to Reichenbach's type description of Thrixspermum luniferum where "Burmah" is mentioned as the country of origin. This

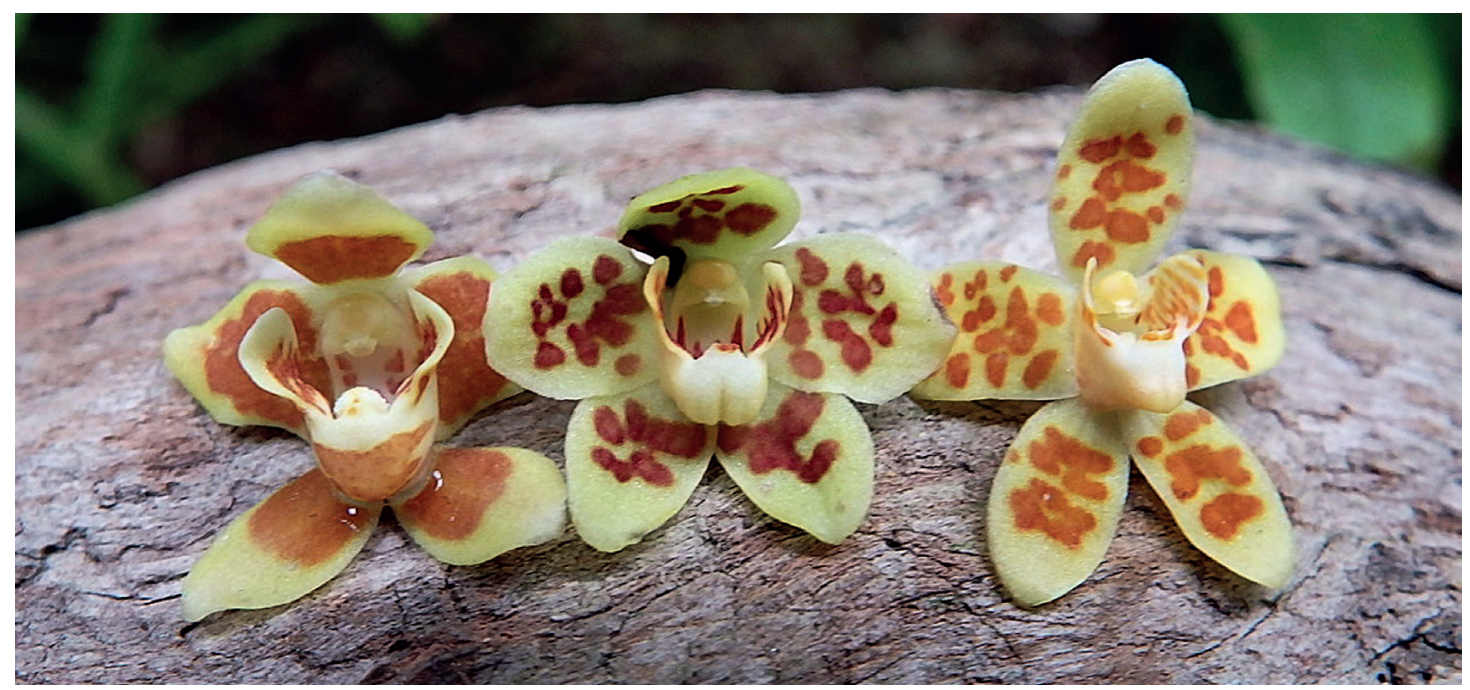

FIgURE 5. The three newly discovered species from Bhutan. From the left: Chiloschista densiflora, C. gelephuense, C. himalaica. Photos by Stig Dalström. 


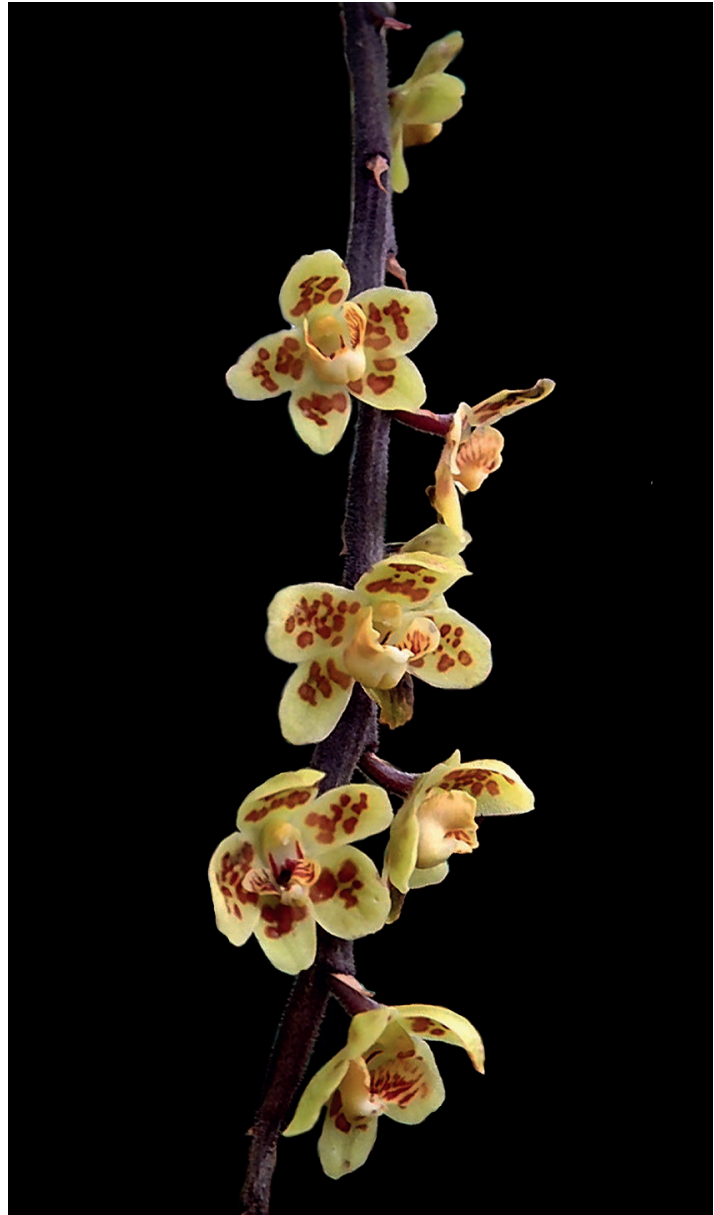

FiguRE 6. Chiloschista gelephuense (S. Dalström 4212). Photo by Stig Dalström.

illustrated species then appeared as "Sarcochilus luniferus Rchb.f." in George King's and Robert Pantling's beautifully illustrated treatment of The Orchids of the Sikkim-Himalaya (King \& Pantling 1898), which moves the geographical origin of the plant from "Burma" to Sikkim-Himalaya (Fig. 12). The general appearances, descriptions, morphology, and origin of the voucher plants for these two illustrations make us conclude that they represent the same species. But since the name "Thrixspermum luniferum" is older and validly published we have to give priority to that name, no matter how "badly constructed" the generic name may be. The argument about which of these two names to be used for this species was temporarily settled by Johannes Jacobus Smith, who transferred it

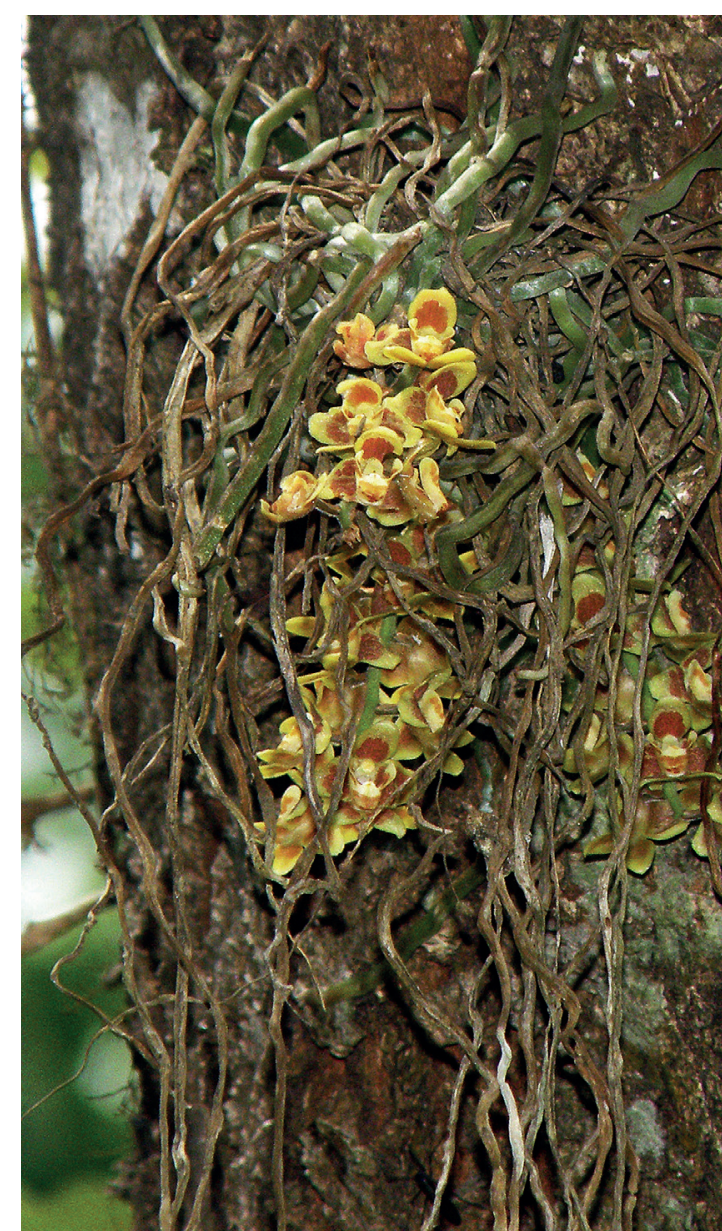

FIgURE 7. Natural habit of Chiloschista densiflora above the town of Gomphu in the Zhemgang district of Bhutan. Photo by Stig Dalström.

to Chiloschista lunifera (Rchb.f.) J.J.Sm., in his Flore de Buitenzorg (Smith 1905). Sadanand N. Hegde included "Chiloschista lunifera" in his treatment of the orchids of Arunachal Pradesh (Hegde 1984), possibly influenced by King \& Pantling.

But is this species from the Sikkim-Himalaya and elsewhere in the Himalayan region the same as what Heinrich Gustav Reichenbach originally described as T. luniferum? We believe not! When analyzing the type description by Reichenbach (1868), we can see that he was aware of the potential criticism for his choice of generic name as he writes: "Thrix-sper-mum! What an ugly name some will say". But what is of more interest to us is that he also mentions: "It is very interesting, in a geographical point of view, that Burmah [Myanmar] 


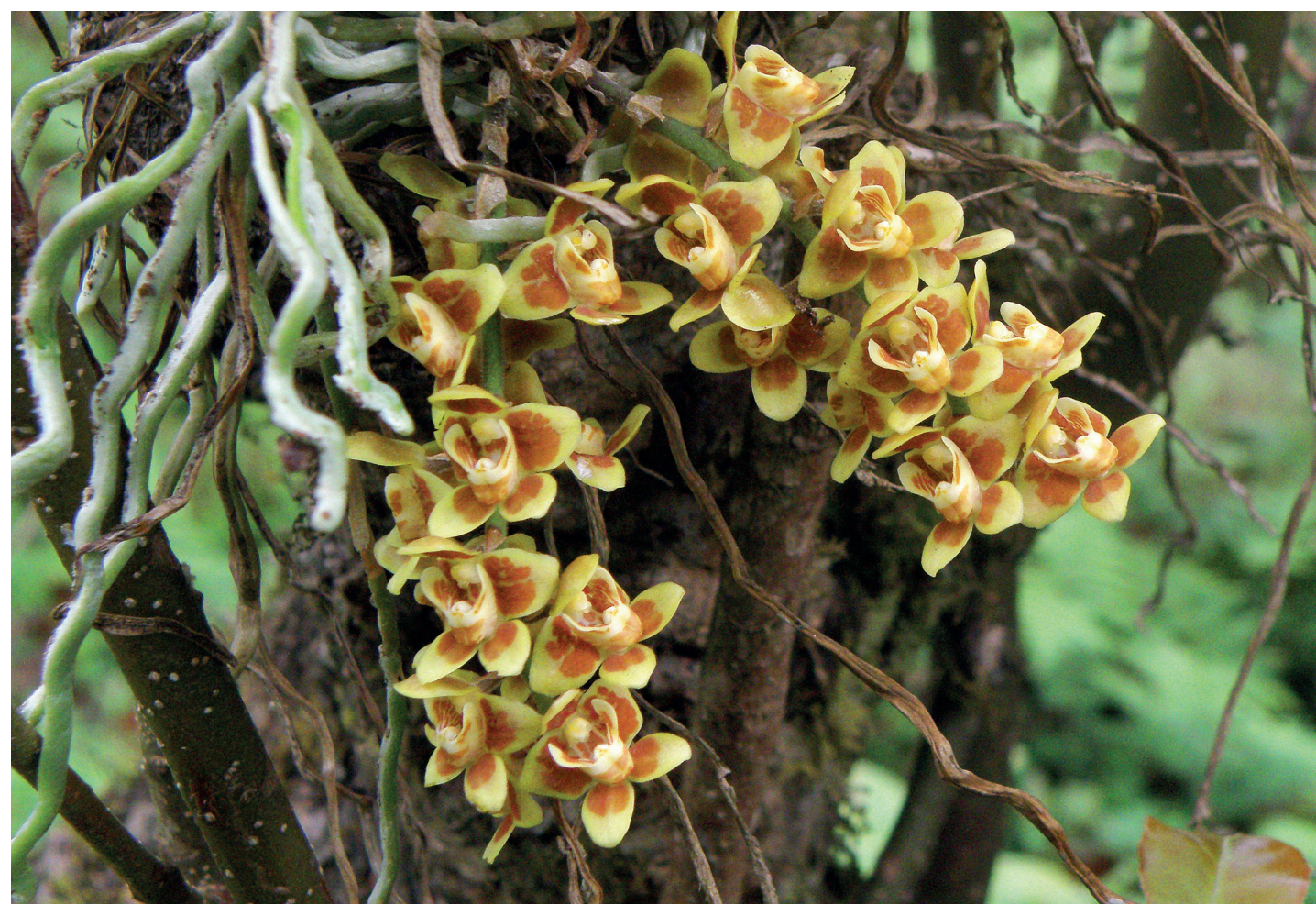

FiguRE 8. Chiloschista densiflora displaying the dense inflorescences from which the specific name is derived. Photo by Stig Dalström.

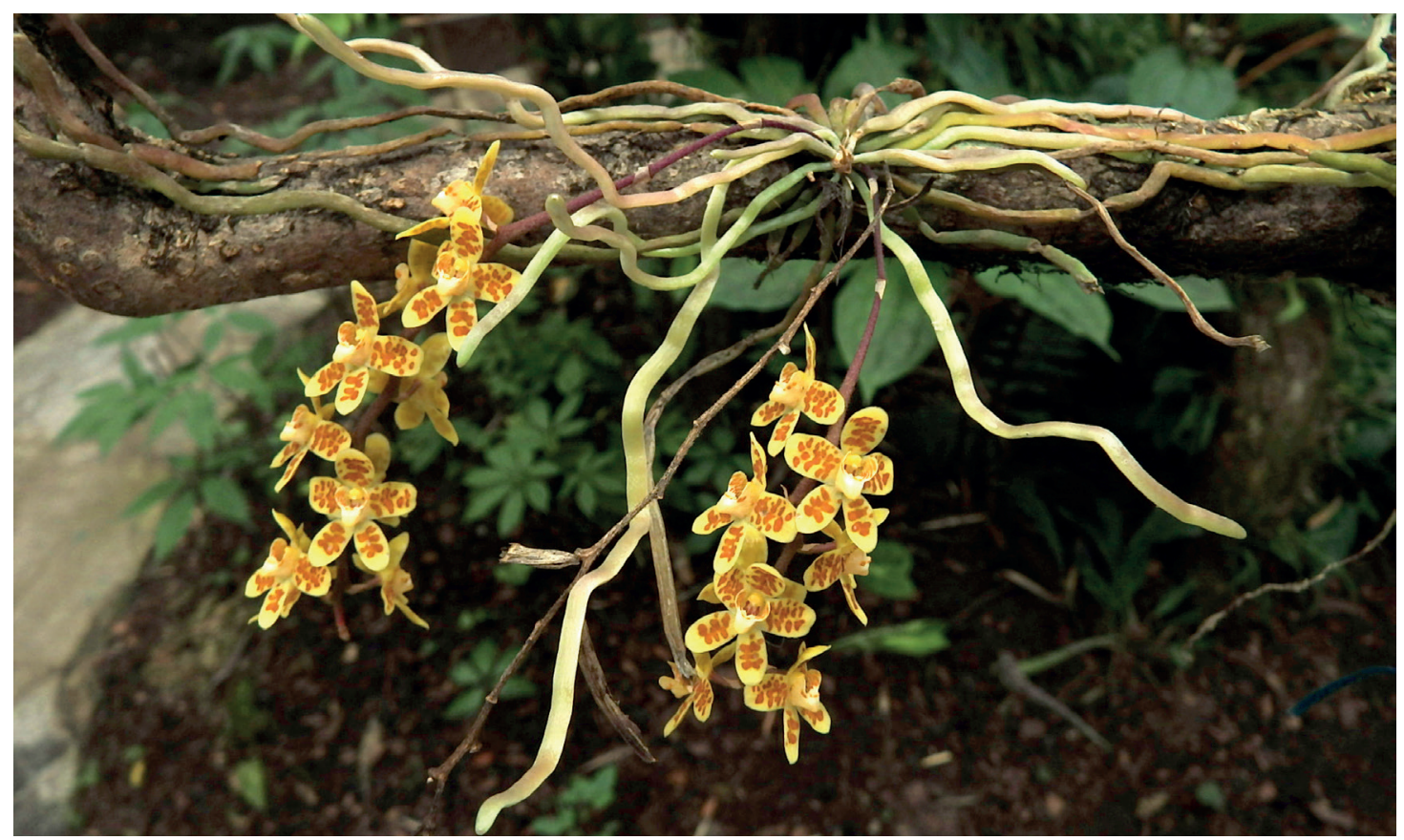

FiguRE 9. Chiloschista himalaica, from near Chenlakha in the Chhukha district, flowering in cultivation in May, 2015, at the Royal Botanic Garden, Serbithang, Thimphu, Bhutan. Photo by Stig Dalström. 


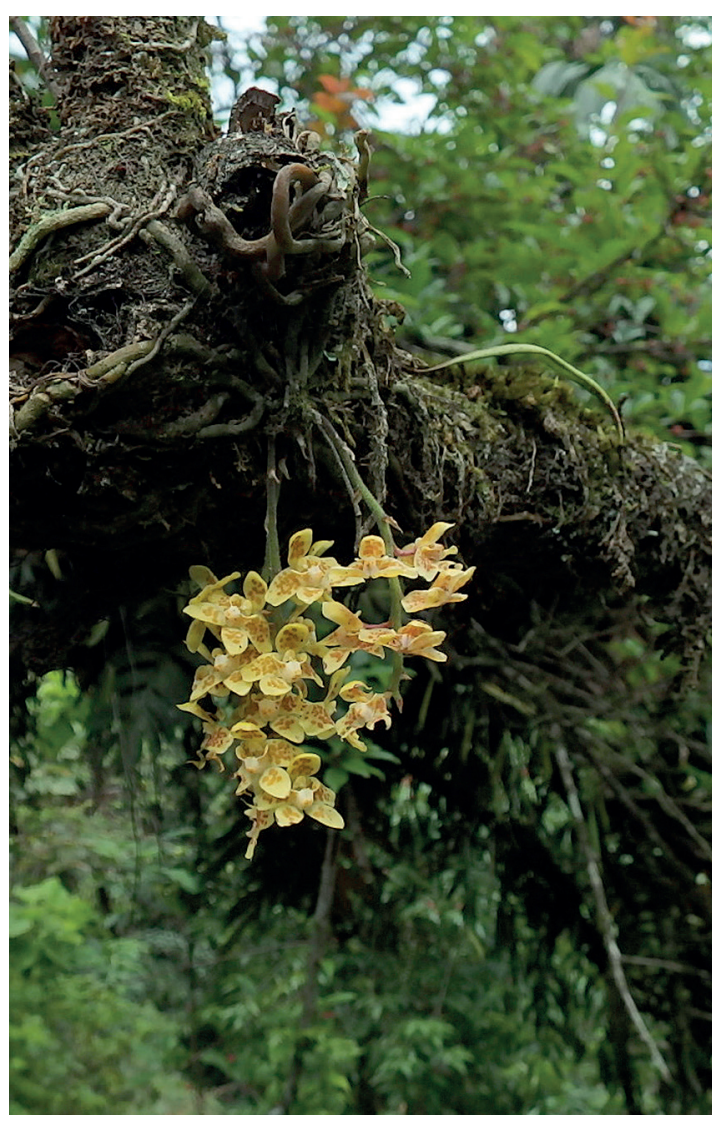

FIgURE 10. Natural habitat of Chiloschista himalaica near Gedu in the Chhukha district. Photo by Stig Dalström.

possesses this species". The color of the flower is described as "yellowish, with a brown disc [no spots!], except the white lip which bears purplish rays". It is also mentioned that this "botanical curiosity comes from Messr. Veitch \& Sons" (Reichenbach 1868). The type for T. luniferum at the Museum of Natural History in Vienna, Austria, consists of several dried inflorescences and one dried leafless plant on sheet 41550 , and a colored drawing on sheet 41549 . The drawing shows a flower that is quite different from the flowers featured in Curtis's Botanical Magazine (Hooker 1889), and by King and Pantling (1898) in having the sepals and petals almost covered by a brown "disc" (Fig.13-14). The backside of the flower appears to have hairs, and the shape of the lip shows structural differences (Fig. 15) that distinguishes this species from the hence incorrectly named Himalayan species. It is therefore concluded here that Chiloschista ("Thrixspermum")

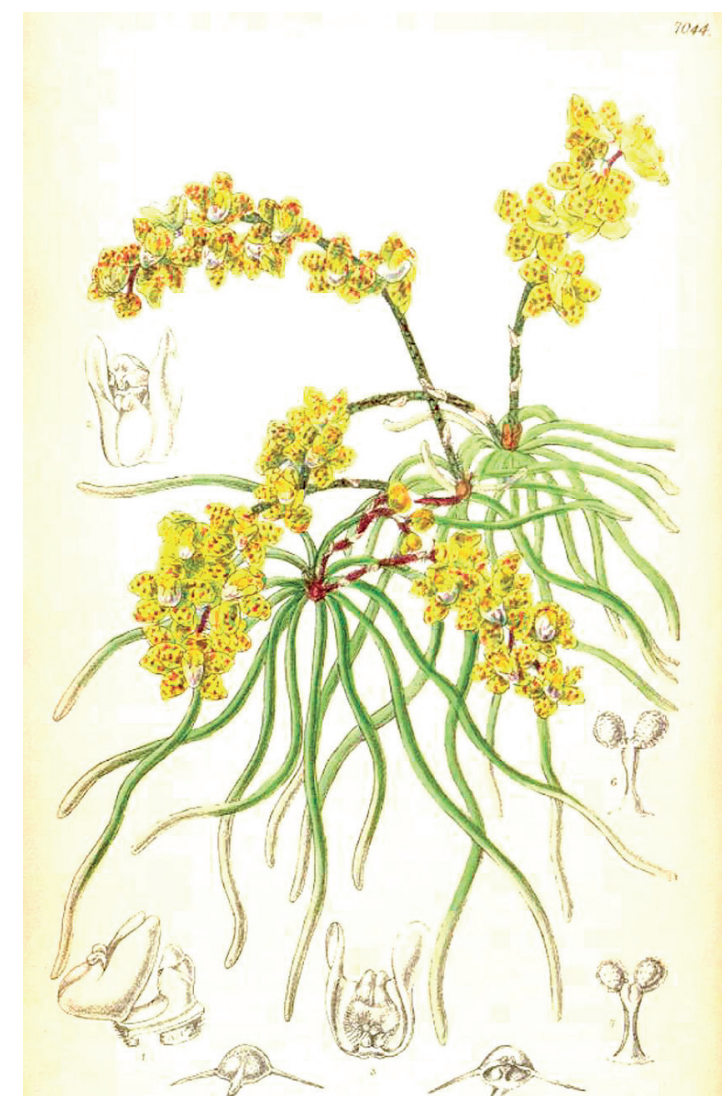

FIgURE 11. Chiloschista himalaica, as "Sarcochilus luniferus" in Curtis's Botanical Magazine, plate 7044 (1889).

lunifera from Myanmar is not the same as the spotted and glabrous species from the Sikkim-Himalaya region, which we are convinced is the same as the second new species from Bhutan, and described in this paper. Gunnar Seidenfaden (1988) unfortunately identifies this latter species as $C$. "parishii", which appears to be the source for the citations by Pearce \& Cribb (2002) and Gurung (2006), and also by H. J. Chowdhery in his treatment of the orchids of the bordering Indian State of Arunachal Pradesh (Chowdhery 1998, Chowdhery \& Pal 2008). This latter citation needs a closer study however. The cited specimens come from "Kameng; between $100-1000 \mathrm{~m}$, on large tree trunks in dense tropical forests" (Chowdhery 1998). With this wide range of altitude it is logical to conclude that there must have been several observations of what has been identified as " $C$. parishii". But when the illustration labeled "Chiloschista parishii" on Fig 111: 193 


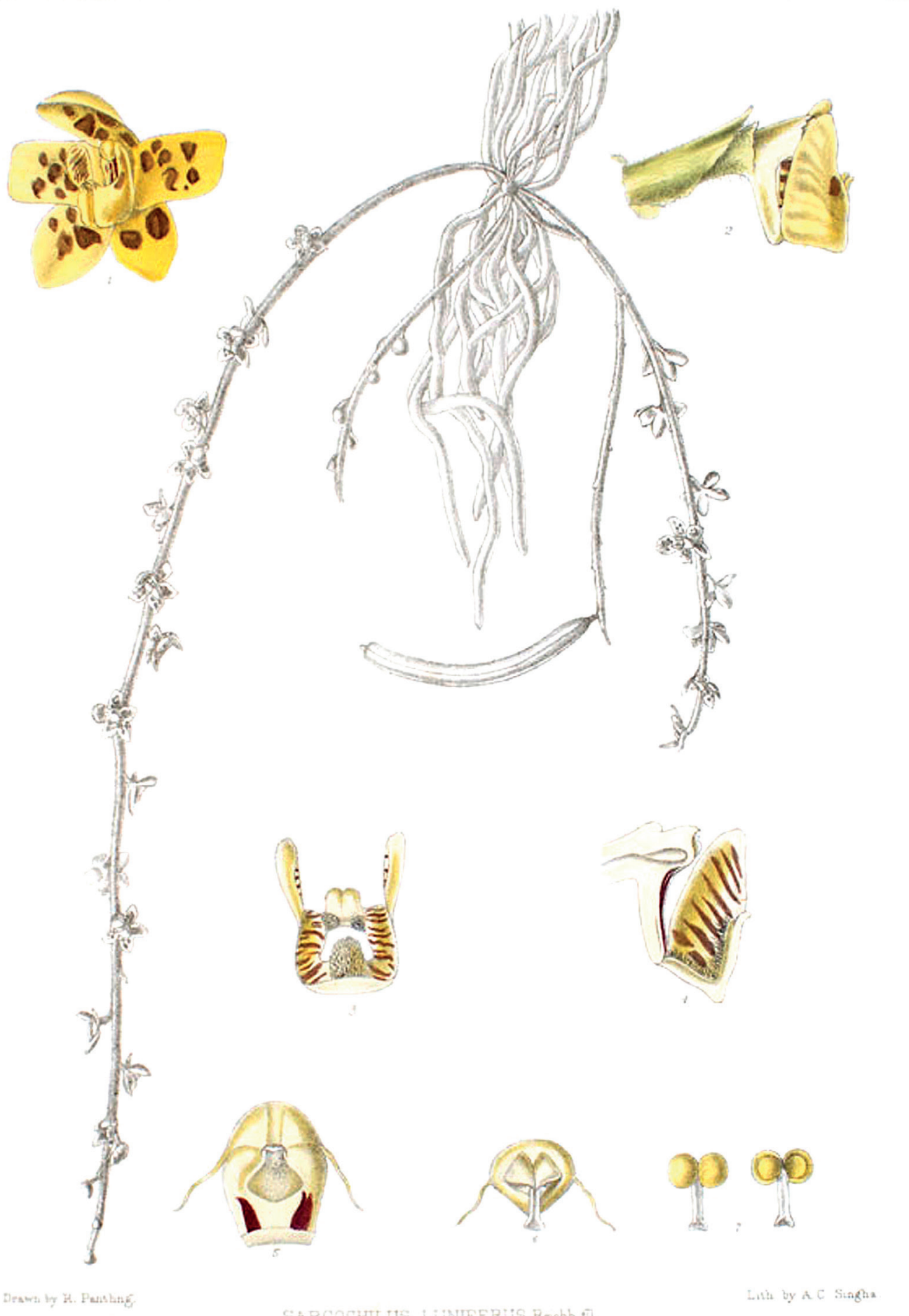

FIGURE 12. Chiloschista himalaica, as "Sarcochilus luniferus" in King \& Pantling (1898), Orchids of the Sikkim-Himalaya, plate 276.

LANKESTERIANA 20(3). 2020. (C) Universidad de Costa Rica, 2020. 


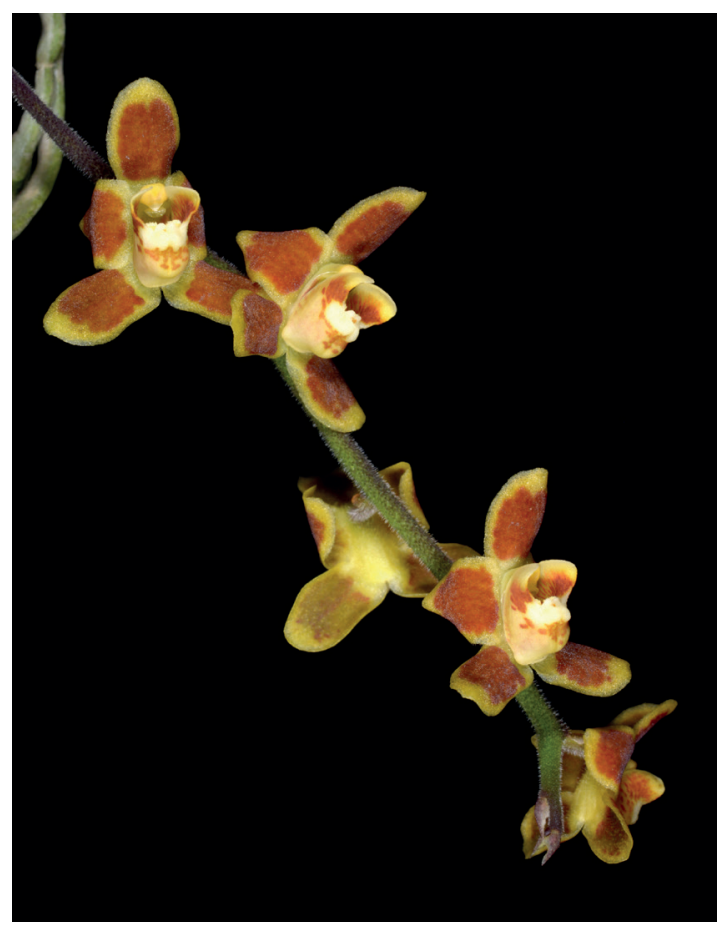

FIgURE 13. Chiloschista lunifera, cultivated by Jeff Tyler. Photo by Ron Parsons.

(Chowdhery 1998) is examined, it becomes clear that it is copied from the illustration of "Sarcochilus luniferus" in King \& Pantling's treatment of the orchids of Sikkim-Himalaya. And because we have concluded that this illustrated species is not the same as the real C. parishii, we also have to conclude that the plants cited by Chowdhery from Arunachal Pradesh may or may not be the same as the Sikkim-Himalayan species. Considering that we have identified three, possibly four undescribed Chiloschista species from Bhutan alone, the chances are that some of the " $C$. parishii" observations from Arunachal Pradesh also represent undescribed species, or at least are not all the same. We therefore encourage local orchid authorities and students to do a closer study of Chiloschista plants that occur in Arunachal Pradesh. We also need to find distinguishing features that tell the real C. parishii apart from the Himalayan species. This is most easily done by looking at the back of the sepals and petals, which are densely pubescent in $C$. parishii while virtually glabrous to basally micro-pubescent in both of the hitherto unnamed Himalayan species, as well as in $C$. gelephuense.

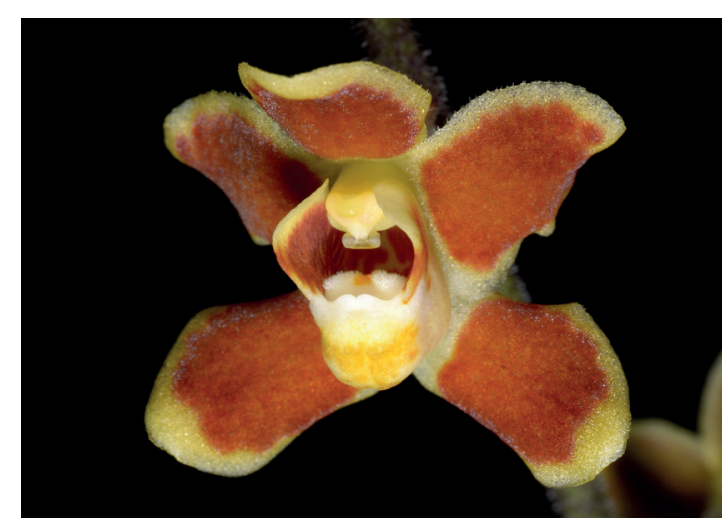

FIGURE 14. Close-up of a flower of Chiloschista lunifera that correlates with the type description of this species. Plant cultivated by Jeff Tyler. Photo by Ron Parsons.

Chiloschista glandulosa Blatt. \& McCann is another spotted species that was described in the Journal of the Bombay Natural History Society by Ethelbert Blatter and Charles McCann (1932). The description is based on a plant collected in North Kanara, which is a stretch of land in the Indian state of Karnataka, on the western coast and about halfway down the Indian Peninsula, and very far from the Himalayan region. Chiloschista glandulosa appears to be similar in coloration to the unnamed SikkimHimalayan species but is overall smaller in size. The side-lobes of the lip are described as "more than twice as long as the midlobe", while scarcely twice as long (high) in the Himalayan species. The column foot is only $1 \mathrm{~mm}$ long and as long as the column itself, as opposed to $c a .3 \mathrm{~mm}$ long and distinctly longer than the column for the Himalayan species. These and other dimensional differences, in addition to the very remote natural habitat, convince us to treat these taxa as separate species. Seidenfaden (1988) adds a twist to this conclusion, however, when he writes: "Santapau and Kapadia (1962: 401) say it [C. glandulosa] is conspecific with what they call $C$. lunifera, stating that their material from the area exactly agrees both with the descriptions and figures given by J. J. Smith (which is C. javanica) and by King \& Pantling (which I call C. parishii)". Santapau and Kapadia also writes: "There seems to be little difference between this species [C. glandulosa] and C. usneoides Lindl., as has been pointed out by Hooker f., who however, keeps them apart merely on the basis of colour difference 

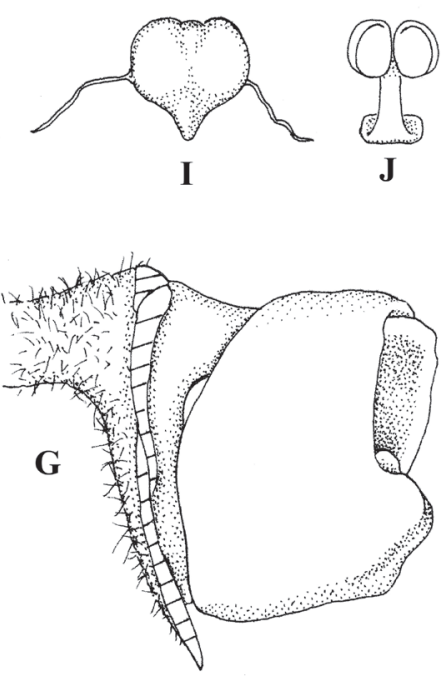

$5 \mathrm{~mm}$

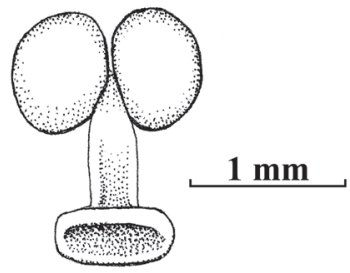

$\mathbf{K}$

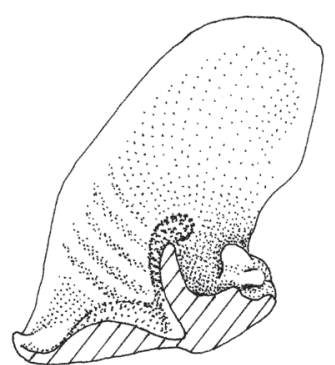

H

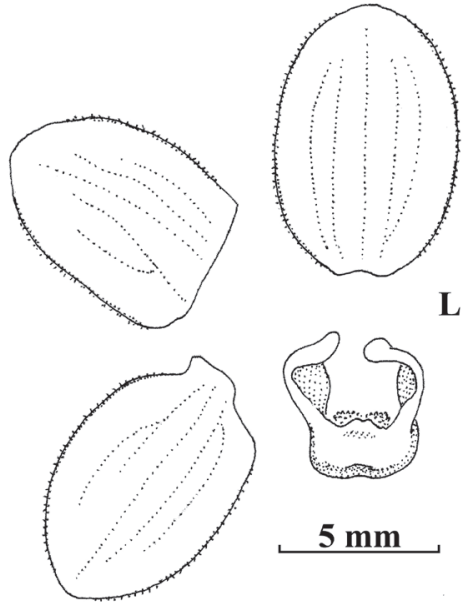

$\mathbf{L}$

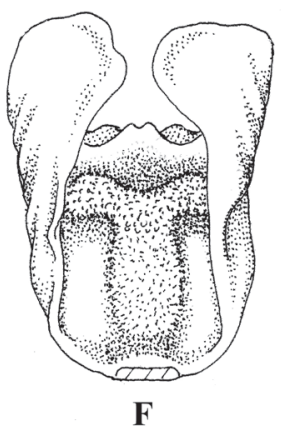

$\mathbf{E}$
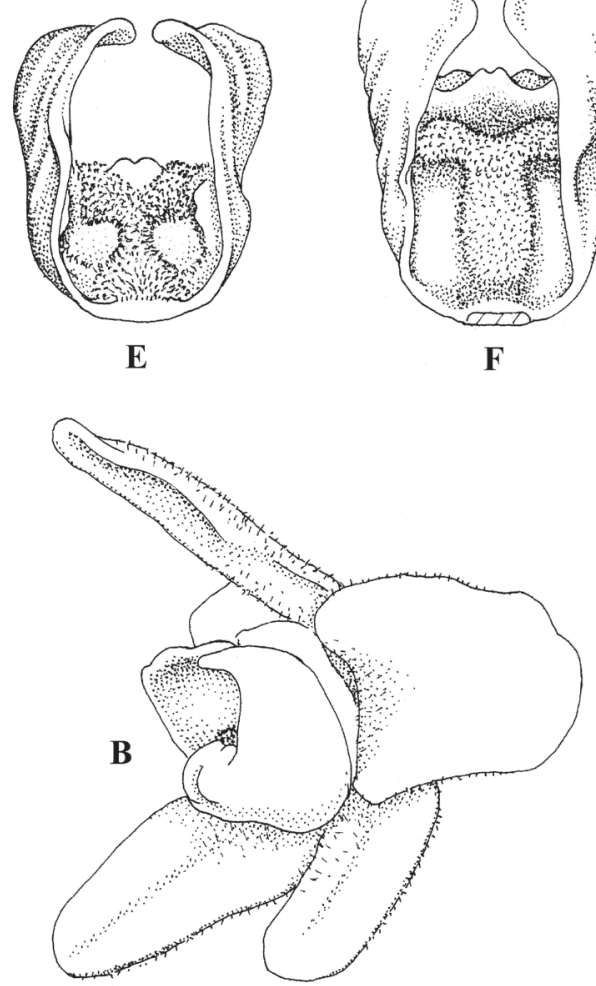

$5 \mathrm{~mm}$

Figure 15. Chiloschista lunifera. A. Flower, front view. B. Flower, front-angled view. C. Column, lateral view. D. Column, front view. E. Lip, back view. F. Lip, dorsal view. G. Column and lip, lateral view. H. Lip sliced vertically, lateral view. I. Anther cap, dorsal view. J. Pollinarium, front view. K. Pollinarium enlarged, back view. L. Flower dissected. Drawn from OIC 7625 (SEL) by Stig Dalström. 
in flowers. J. J. Smith is of the opinion that the two species may be identical" (Santapau \& Kapadia 1962). This wording by Santapau and Kapadia highlights the problems with identifying and distinguishing species that have not been thoroughly examined. And when in doubt it is too easy to follow somebody else's opinion and accept an overly broad species definition. We certainly agree with Seidenfaden's conclusion that Johannes Jacobus Smith's C. "lunifera", collected by Mr. Weghake at Boemiredjo, near Malang, Java (Smith 1905) is the same as C. javanica Schltr., and that it is not the same as the original Chiloschista (Thrixspermum) lunifera from Myanmar, described by Reichenbach. Smith's description clearly refers to a flower that is "grüngelb mit gelbbraunen Flecken" ["greenish yellow with yellowish-brown spots"] in addition to having "Rande ziemlich grob abstehend behaart" ["margins with coarse erect hairs"; in reference to the sepals and petals]. In Rudolf Schlechter's original description of $C$. javanica he writes: "Die letztere is von der Hiamalya-Pflanze spezifisch verschieden durch die mer sicheligen, spitzen Seitenlappen, die bewimperten Sepalen und Petalen und die viel kürzeren seitlichen Auswüchse der Antheren." ["The latter (here referring to C. javanica) is specifically different from the Himalayan plant (here erroneously referring to the un-named Sikkim-Himalayan species named as 'Sarcochilus. luniferus' by Bentham \& Hooker, and King \& Pantling, which has glabrous sepals and petals) by the more sickle-shaped and pointed side-lobes, the ciliate (or marginally hairy) sepals and petals and the much shorter 'appendages' of the anther"] (Schlechter 1919). These descriptions effectively remove C. javanica (Fig. 16) from the discussion since the unnamed Himalayan species has no distinct hairs on the sepals and petals. Chiloschista javanica is considered synonymous with $C$. lunifera by the World Checklist of Selected Plant Families (Govaerts 2020) but this is clearly a mistake since there are no visual or morphological similarities between these two taxa. Seidenfaden's conclusions may be correct in reference to the differences between C. glandulosa, C. javanica and C. lunifera, but this is also where the confusion with the identity of his $C$. parishii enters the picture (Seidenfaden 1988). Based on differences in size, flower morphology and the presence or absence of hairs on the backside of the

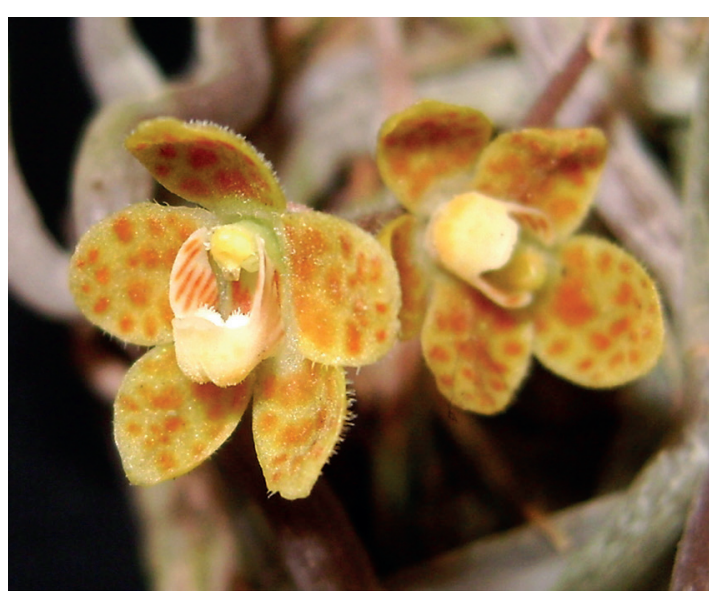

Figure 16. Chiloschista javanica. Photo by Destario Metusala.

sepals and petals, we disagree with Seidenfaden and claim that the Himalayan species featured in Curtis's Botanical Magazine (Hooker 1889) and The Orchids of the Sikkim-Himalaya (King \& Pantling 1898), in addition to the Chiloschista species from the Trongsa and Zhemgang districts mentioned above, are different from C. glandulosa, C. lunifera and C. parishii and represent unnamed species which are described below.

In March, 2020, Forest Ranger Bhakta Bdr. Ghalley brought his family to a short walk along the Wang Chhu river below the Chhukha Powerhouse in the Chhukha district (Fig. 17). There, he discovered plants in bloom of a small-flowered and spotted Chiloschista that looked "different" to him (Fig. 18-19). The flowers are unusually small, whitish with dark brown spots, and presented on very short inflorescences. The internal morphology of the flower, however, correlates fairly well with the second new species described here, so it is treated as a slightly deviating geographic form of that species for the time being.

Based on recent phylogenetic analysis, the genus Chiloschista is considered a monophyletic and distinct clade related to the Phalaenopsis clade, the Thrixspermum clade and the Vanda clade in the Aeridinae (Zou et al. 2015). The number of accepted species varies however, from 10 (Chen \& Wood 2009, Wood 2014) to 22, and yet not including $C$. javanica (Govaerts 2020). This illustrates the existing disagreements among taxonomists and ensures that the last word is yet to be spoken about how to treat them scientifically and nomenclaturally. 


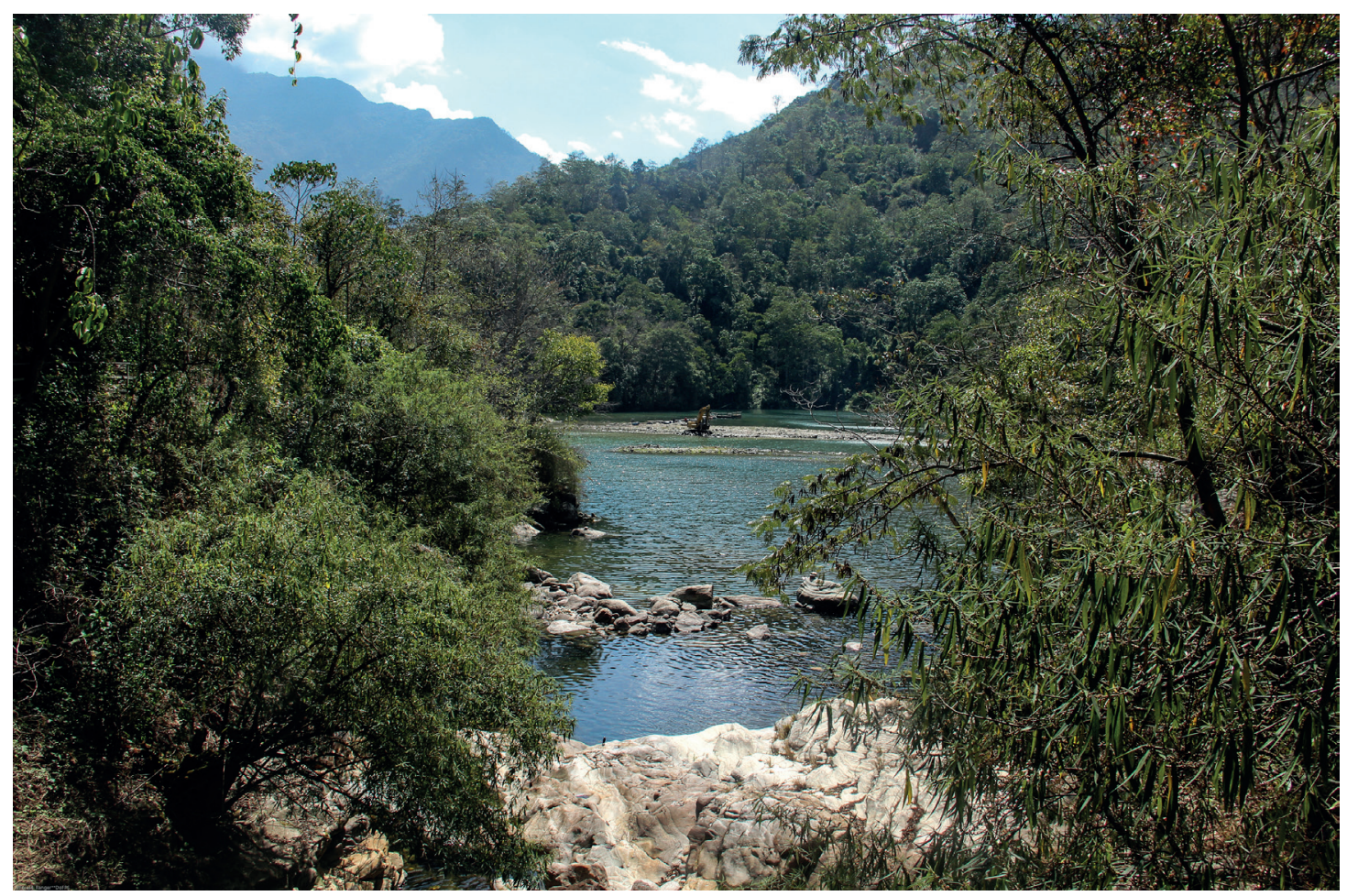

FIGURE 17. A serene view of the Wang Chhu river in the Chhukha district. Photo by Bhakta Bdr. Ghalley.

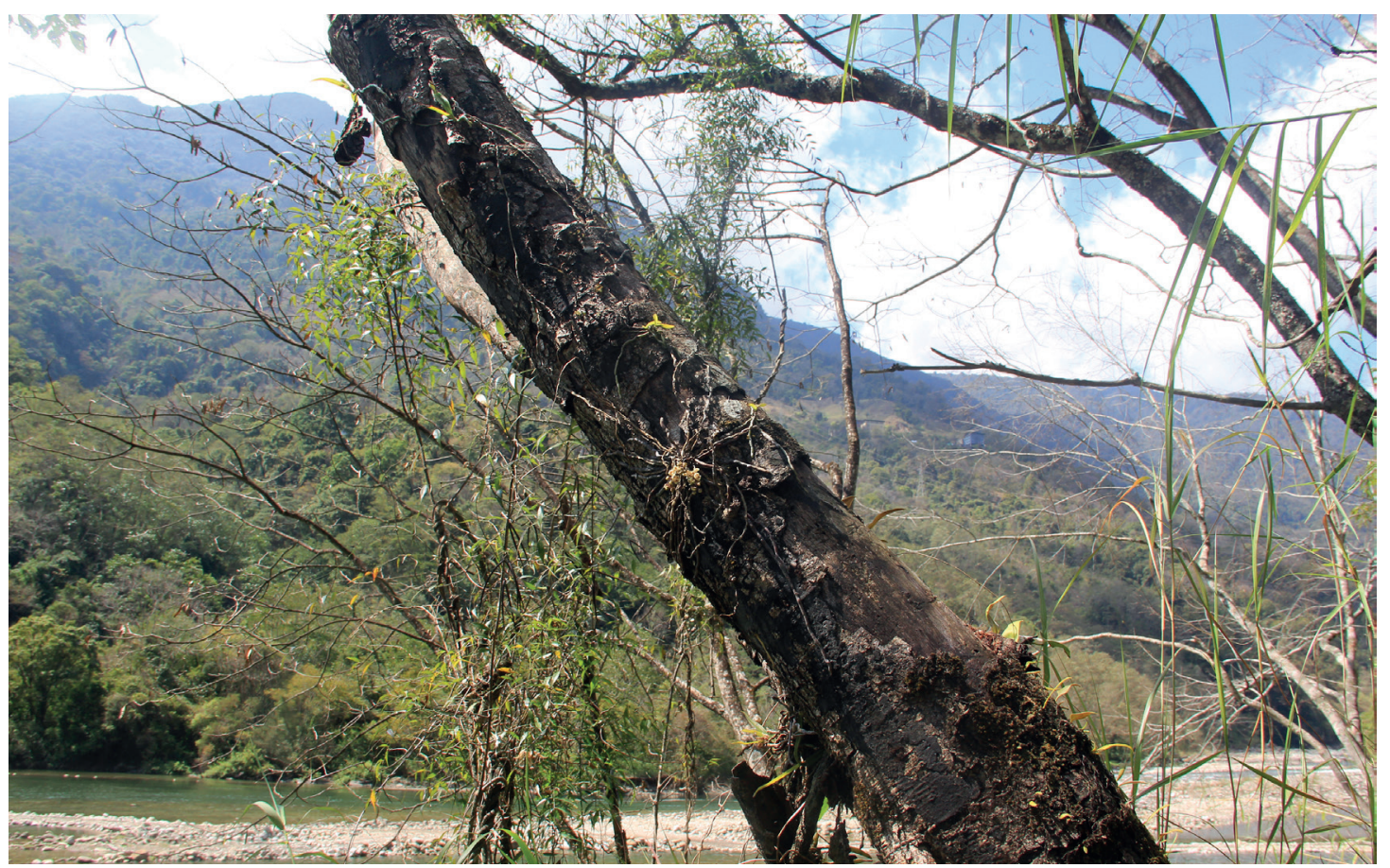

FIgURE 18. Natural habit of Chiloschista $\mathrm{cf}$. himalaica along Wang Chhu river in the Chhukha district. Photo by Bhakta Bdr. Ghalley. 


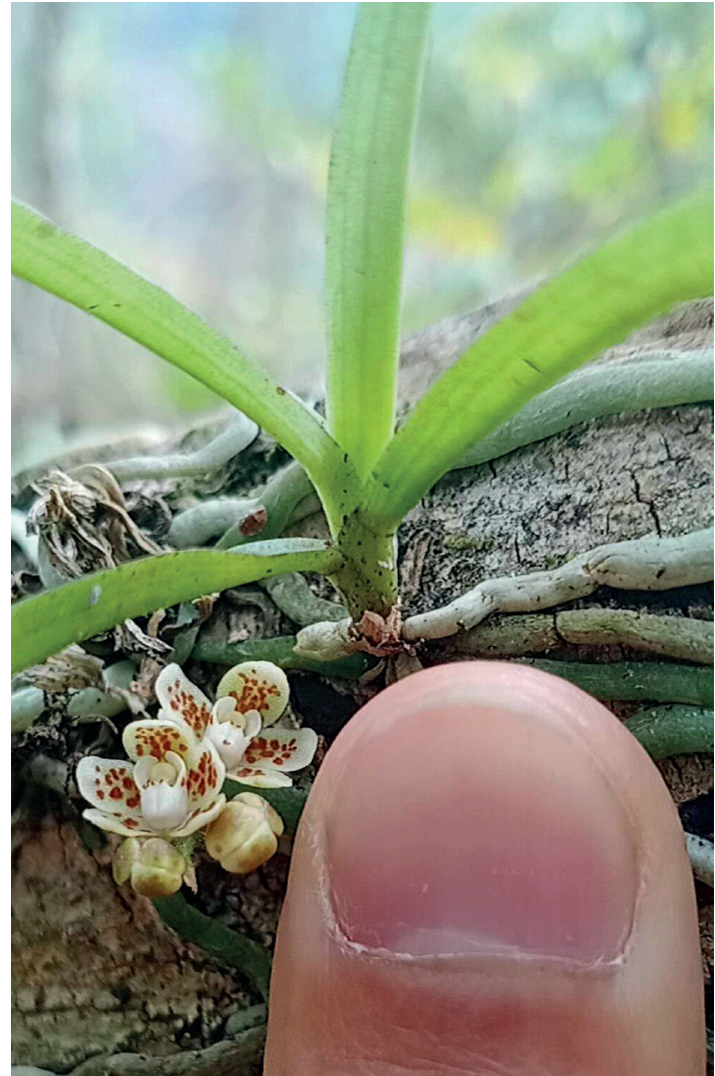

Figure 19. The diminutive flowers of Chiloschista cf. himalaica that grows along the Wang Chhu river in the Chhukha district. Photo by Bhakta Bdr. Ghalley.
In conclusion, the recent discovery of three and possibly four new Chiloschista species from a small country such as Bhutan (Fig. 20) suggests that an untold number of additional new Chiloschista taxa may be waiting to be discovered in the Himalayan region and throughout southeastern Asia. This in turn should encourage Forest Rangers, students, scientists and orchid enthusiasts in general to keep searching for these miniature "jungle jewels".

\section{TAXONOMIC TREATMENT}

Chiloschista densiflora Gyeltshen, C.Gyeltshen \& Dalström, sp. nov. (Fig. 4-6, 21-22).

TYPE: Bhutan. Zhemgang: Gomphu, epiphyte on Quercus lamellosa Sm., above the village, N2701'34.07'; E9047'32.91”, altitude $1515 \mathrm{~m}$, 7 May, 2014, S. Dalström 4216 (holotype: THIM; specimen preserved in alcohol).

Diagnosis: Chiloschista densiflora is superficially similar to $C$. parishii from Myanmar and Thailand in having yellowish flowers with brown spots on the sepals and petals, but differs by the larger flower, $c a$. $12-13 \mathrm{~mm}$ across versus $8-10 \mathrm{~mm}$ across for the latter species, and with virtually glabrous to indistinctly micro-pubescent sepals and petals versus being densely pubescent for $C$. parishii. Chiloschista densiflora is

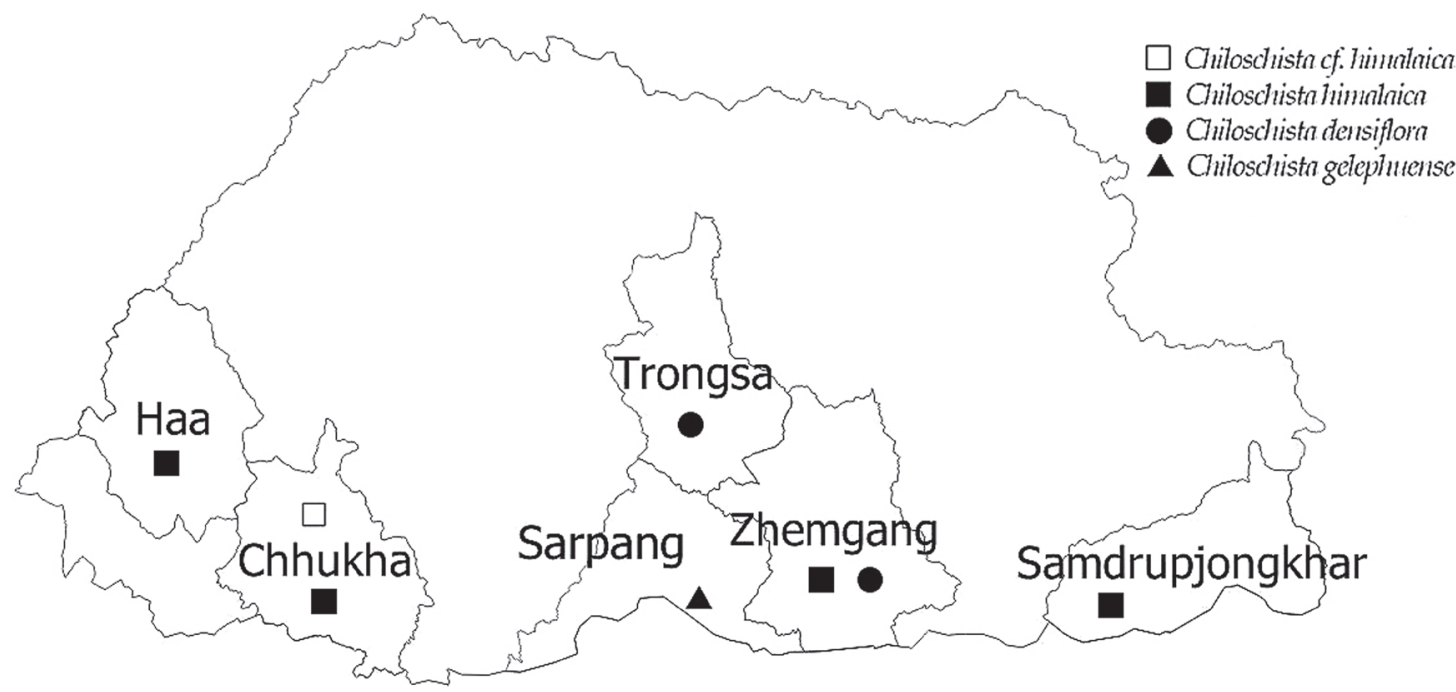

FIgURE 20. Map of Bhutan with documented locations for spotted Chiloschista species indicated. Map composed by Choki Gyeltshen. 

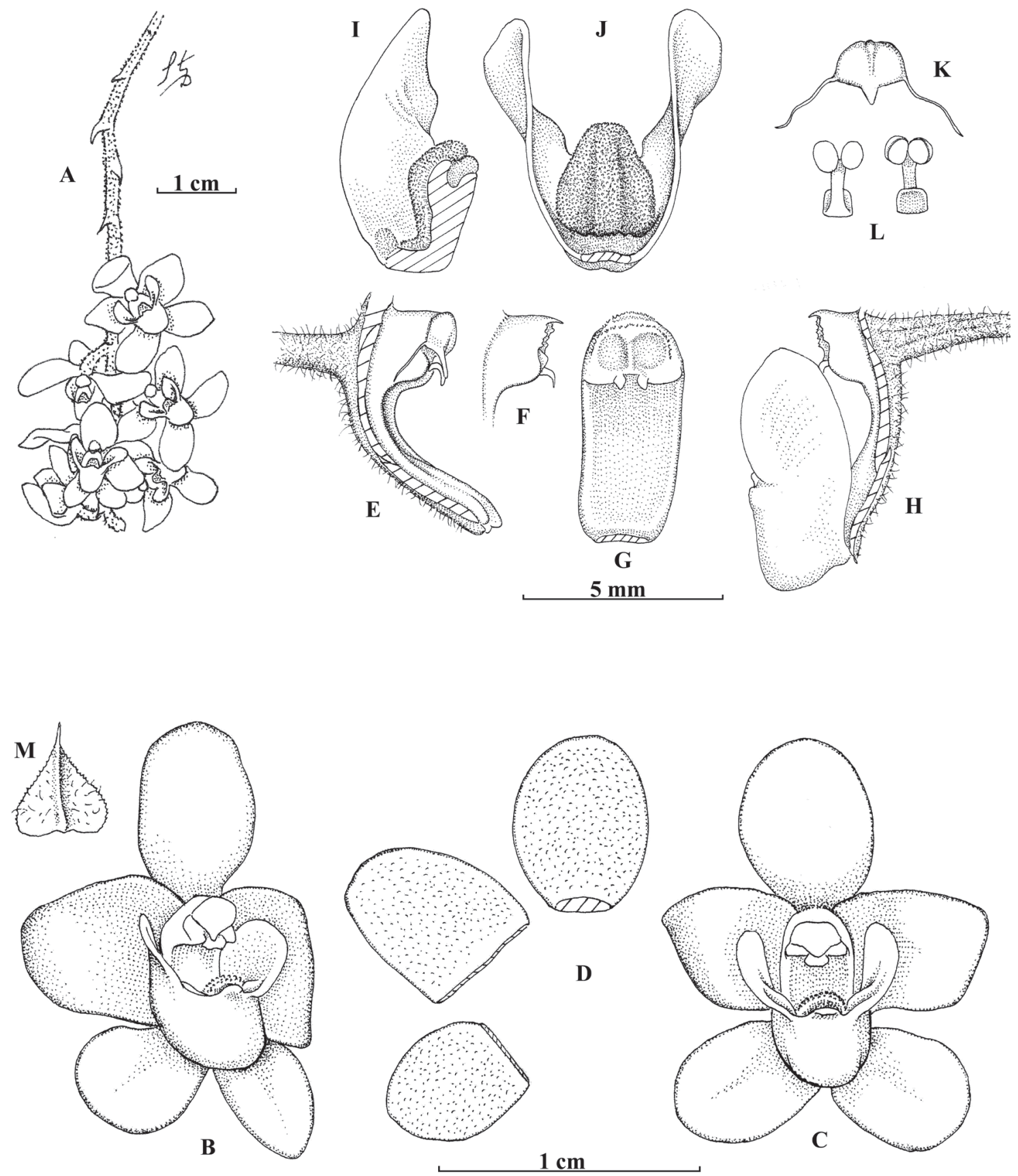

Figure 21. Chiloschista densiflora. A. Inflorescence (excluding the roots, stem and leaf). B. Flower, front-angled view. C. Flower, front view. D. Sepals and petals, back views. E. Column, lateral view. F. Apex of the column without the anther cap, lateral view. G. Column, front view. H. Column and lip, lateral view. I. Lip sliced vertically, lateral view. J. Lip, back view. K. Anther cap, dorsal view. L. Pollinarium, front and back views. Drawn from the holotype (S. Dalström 4216, THIM) by Stig Dalström. 


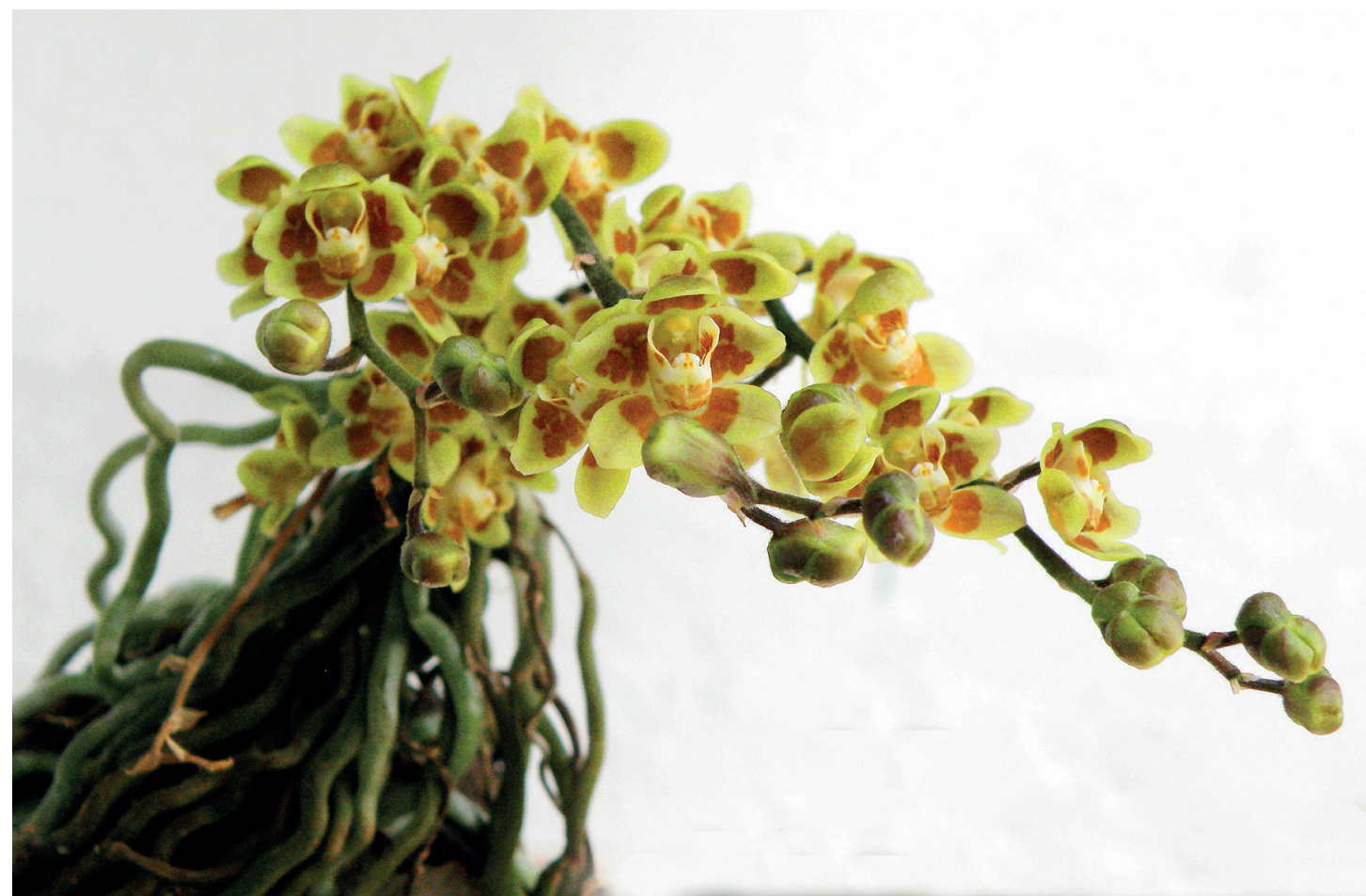

FIGURE 22. Chiloschista densiflora, cultivated at the Royal Botanic Garden, Serbithang, Thimphu Bhutan. Photo by Stig Dalström.

distinguished from other similarly colored currently described species by the sub-triangular, apically rounded, glandular pubescent callus lobe inside the lip.

Epiphytic herb. Roots numerous, spreading, terete to slightly flattened, $2-3 \mathrm{~mm}$ thick. Stem minute, virtually absent. Leaves are seasonal in the wild during the rainy period and not seen on the type. Inflorescence pendent, $c a .7 \mathrm{~cm}$ long on type, but longer inflorescences have been observed, almost straight, micro-pubescent, densely $c a$. 11-flowered; peduncle $c a .1 .5 \mathrm{~cm}$ long; rachis ca. $4.5 \mathrm{~cm}$ long; bracts scale-like, ventrally keeled and pubescent, narrowly acute to acuminate, $c a$. $4 \mathrm{~mm}$ long. Pedicel with ovary micro-pubescent, $c a .5$ $\mathrm{mm}$ long. Flower with rather flat and spreading sepals and petals, with the lateral sepals slightly bent forward under the lip, ca. 12-13 mm across; dorsal sepal dull yellow with commonly a large brown spot, externally basally micro-pubescent, internally minutely micropubescent, broadly elliptic, apically broadly obtuse to almost orbiculate, $c a .7 \times 5.0-5.5 \mathrm{~mm}$; lateral sepals similar in color and pubescence, fused basally along the column foot, sub-sessile, broadly elliptic, apically broadly obtuse to orbiculate, $c a .5 \times 4.0-4.5$ $\mathrm{mm}$; petals yellow with irregular basal brown spots, similarly pubescent as the sepals, sessile and fused to the column foot, indistinctly obliquely and broadly ovate, apically orbiculate, $c a .6 \times 5.0-5.5 \mathrm{~mm}$; lip externally whitish heavily marked with irregular brown marking on the front-lobe and along the frontal edge of lateral lobes, internally dull yellow with brown stripes and markings, rigidly attached to the column foot, deeply saccate, tri-lobed with lateral lobes erect to indistinctly curved inwards or outwards, indistinctly oblique, apically broadly obtuse when flattened, frontlobe short, fleshy, indistinctly bi-lobed and labiate, slightly recurved, $c a .5 .5 \mathrm{~mm}$ high and $6.0-6.5 \mathrm{~mm}$ wide; callus dominated by a fleshy, broad and micropubescent swelling basally, turning into a basally broad, sub-triangular, apically narrowed and rounded, glandular pubescent fleshy structure, creating a small but distinct cavity, or pit, between the apex of the callus and the apex of the front lobe of the lip; column white, very short and stocky, $c a$. 1.4-1.5 mm long, excluding 
the anther cap and the $c a .4 \mathrm{~mm}$ long and sub-linear column foot which is spotted with red-purple; anther cap light yellow, galeate with a pair of hair-like, $c a$. 2.2-2.3 mm long tendrils on each side; pollinarium of a pair of obliquely globose and indistinctly flattened, cleft/folded pollinia on a $c a .1 .5 \mathrm{~mm}$ long, narrowly sub-linear stipe on a sub-quadrate, indistinctly concave viscidium.

PARATYPE: Bhutan. Trongsa: Rescued from forest to be cut in clearance for the Mangde Chhu hydroelectric power station project, collected from citrus trees by Nima Gyeltshen 29 Apr. 2012 (digital photos in Nima Gyeltshen's archives), and flowered in cultivation at the Royal Botanic Garden, Serbithang, May 2013, S. Dalström 4156, 4188, 4200 (THIM; flowers preserved in alcohol).

Distribution: Chiloschista densiflora is currently known from the Trongsa and Zhemgang districts in central Bhutan. Pearce and Cribb (2002) list several collections of Chiloschista "parishii" from Bhutan. We believe that these collections represent one or both of the species described in this paper but have not been able to confirm this.

Etymology: Named in reference to the densely flowered inflorescence.

Chiloschista himalaica Tobgay, C.Gyeltshen, Dalström, sp. nov. (Fig. 12, 23).

TYPE: Bhutan. Chhukha: epiphyte on lower trees along old road to Darla Hydropower Adits. Chenlakha, N26 57'479"; E89 4'414", altitude 1480 m, 19 May 2015, S. Dalström 4225, K. Tobgay \& D. Wangdi (holotype: THIM, specimen preserved in alcohol, digital photos in Dalström archives).

Diagnosis: Chiloschista himalaica is externally similar to and often confused with C. parishii from Myanmar and Thailand, but differs in having slightly larger flowers, $10-13 \mathrm{~mm}$ versus $8-10 \mathrm{~mm}$, and by the glabrous backsides of the sepals and petals, as opposed to being densely pubescent in C. parishii.

Epiphytic herb. Roots numerous, spreading, terete to slightly flattened, $2-3 \mathrm{~mm}$ thick. Stem minute, virtually absent. Leaves are seasonal in the wild during the rainy period and not seen on the type. Inflorescence pendent, $c a .11 \mathrm{~cm}$ long on type, but shorter and longer inflorescences have been observed in the field, basally straight, apically indistinctly flexuous, micropubescent, $c a$. 11-flowered; peduncle $c a .4 \mathrm{~cm}$ long; rachis $c a .7 \mathrm{~cm}$ long; bracts scale-like, acute, ventrally keeled, narrowly acute to acuminate, $c a$. 2-3 mm long. Pedicel with ovary micro-pubescent, ca. $5 \mathrm{~mm}$ long. Flower ca. $10-13 \mathrm{~mm}$ across with more or less spreading sepals and sometimes with recurved petals and with the dorsal sepal frequently bent forward over the column; dorsal sepal yellow with brown spots, externally and basally micro-pubescent, internally minutely micro-pubescent to glabrous, broadly elliptic, apically broadly obtuse to orbiculate, $c a .6 \times 3.5-4.0$ $\mathrm{mm}$; lateral sepals similar in color and pubescence, fused basally along the column foot, sub-sessile, broadly elliptic, apically broadly obtuse to orbiculate, ca. $6 \times 3.5-4.0 \mathrm{~mm}$; petals yellow with brown spots, similarly micro-pubescent to glabrous as the sepals, sessile and fused to the column foot, almost linear to indistinctly ovate, apically orbiculate to truncate, $c a$. $5.5-6.0 \times 3.5 \mathrm{~mm}$; lip externally whitish more or less marked with irregular brown marking on the front-lobe and along the frontal edge of lateral lobes, internally whitish to pale yellow with red-brown stripes and markings, rigidly attached to the column foot, deeply saccate, tri-lobed with lateral lobes erect to indistinctly curved inwards or outwards, indistinctly oblique, apically broadly obtuse to orbiculate when flattened, front-lobe short, fleshy, bi-lobed and labrose, slightly recurved, $c a$. 4.6-5.0 $\mathrm{mm}$ high and $4.5-5.0 \mathrm{~mm}$ wide; callus dominated by a fleshy, broad and micropubescent swelling basally, turning into a basally broad, apically narrowed, glandular pubescence with an erect row of distinct glandular hairs, apically split into two spreading cushions, creating a small but distinct cavity, or pit, between the apex of the glandular callus and the labrose front lobe of the lip; column white, very short and stocky, $c a$. 1.5-2.0 mm long, including the anther cap, and with a $c a .3 \mathrm{~mm}$ long and slightly broadened column foot, which is striped along the edges with red-purple; anther cap light yellow, galeate with a pair of hair-like, $c a$. 1.0-1.2 mm long tendrils on each side; pollinarium of a pair of obliquely globose and indistinctly flattened, cleft/folded pollinia on a $c a .1 \mathrm{~mm}$ long, narrowly sub-linear stipe, on a sub-rectangular, indistinctly concave viscidium. 

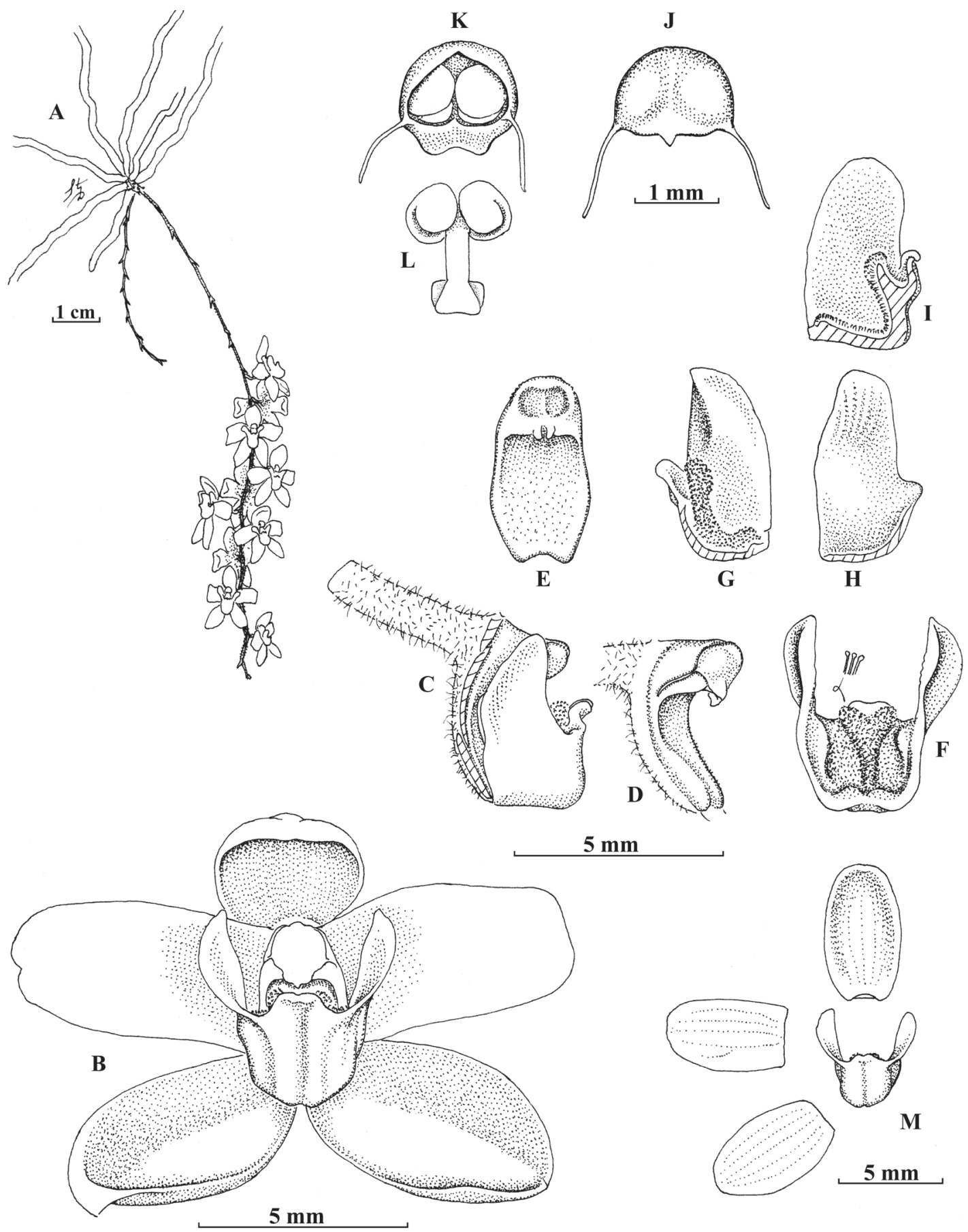

Figure 23. Chiloschista himalaica. A. Plant habit. B. Flower, front view. C. Column and lip, lateral view. D. Column, lateral view. E. Column, front view. F. Lip, back view. G. Lip sliced vertically when it includes the callus, lateral view. H. Lip sliced vertically when it excludes the callus, lateral view. I. Lip sliced vertically through the callus, lateral view. J. Anther cap, front view. K. Anther cap with pollinia, back view. L. Pollinarium, front view. M. Flower dissected. Drawn from the holotype (Dalström 4225, THIM) by Stig Dalström. 


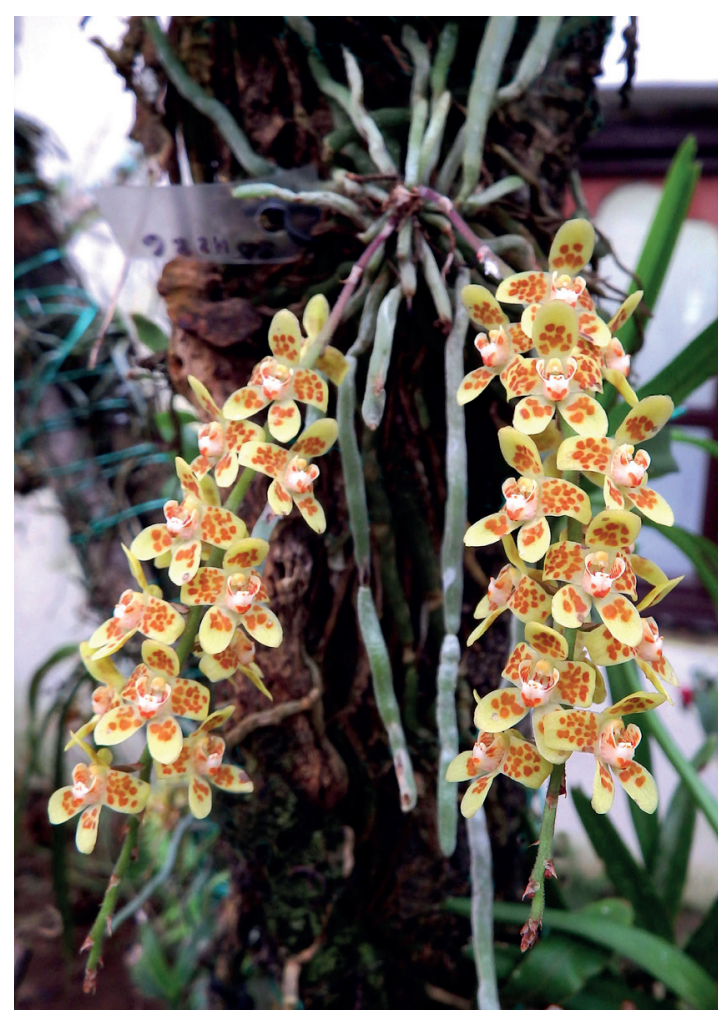

Figure 24. Chiloschista himalaica cultivated at the Royal Botanic Garden, Serbithang, Thimphu, Bhutan. Photo by Stig Dalström.

PARATYPES: Bhutan. Haa: Shebji, plants without flowers collected on 22 Sep. 2011, altitude $c a .1400$ m, and flowered in cultivation at the Royal Botanic Garden, 6 May, 2012, S. Dalström 4183, 4198 (THIM, flowers preserved in alcohol; digital photos in Dalström archives). Shaba, Sangbeykha geog, epiphyte on Ficus sp. N27¹1'3.31"; E89 8'24.72”, altitude 1500 $\mathrm{m}$, observed in bloom by forestry officials of the Jigme Khesar Strict Nature Reserve (JKSNR) while conducting Local Forest Management Planning survey in May 2019, B. B. Ghalley s.n. (digital photograph in Ghalley and Dalström archives). Sangbeykha geog, Bebji. N27 8'22.45"; E89 6'13.95", altitude 1550 $\mathrm{m}$, observed in bloom by forestry officials of the JKSNR while conducting Local Forest Management Planning survey in May 2019, B. B. Ghalley s.n. (digital photograph in Ghalley and Dalström archives). Chhukha: Along the old road to Darla Hydropower Adits., epiphyte Chenlakha, on smaller trees (Maesia chisia Buch.-Ham, and Gymnosporia rufa (Wall.)

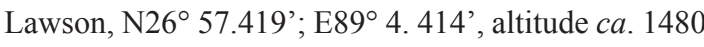
m, 19 May 2015, S. Dalström 4224, K. Tobgay \& D. Wangdi; S. Dalström 4226, K. Tobgay \& D. Wangdi (both at THIM, flowers preserved in alcohol, digital photographs in Dalström archives). Chhukha: Below Chhukha Powerhouse in warm broad-leaved forest along the Wang Chhu river, epiphytic on a dead oak, N27 2'59.59”; E89 34'52.43”, altitude. ca. 1374 $\mathrm{m}$. This collection consist of very small plants with smaller than usual flowers of a pale whitish color with less than usual purple striations and spots, but the flower morphology is too close to the typical form to be considered as a different taxon at this time, $B . B$. Ghalley s.n. (THIM). Zhemgang: Bjoka, epiphyte in clusters on Ficus auriculata Lour., N26 97.229'; E91 ${ }^{\circ}$ 053.398', altitude $c a .1090 \mathrm{~m}$, plants collected without flowers 11 Feb. 2018, and flowered in cultivation at the Royal Botanic Garden 15 May 2018, S. Dalström 4276 (digital photographs in Dalström's and Kezang Tobgay's archives). Samdrup Jongkhar: Gomdar, on low shrubs and gnarled trees on limestone outcroppings in association with Paphiopedilum fairrieanum, altitude ca. 1800 m, S. Dalström 4207, 4214 (THIM, flowers preserved in alcohol).

Distribution: Chiloschista himalaica is currently known from the Chhukha, Haa, Samdrupjongkhar and Zhemgang districts in Bhutan, as epiphytes at 1000-1800 m, and flowers May-July (Feb.-Mar., for the Chhukha Powerhouse population). It is also confirmed from Nepal and the tropical range of the Indian Himalayas. Pearce and Cribb (2002) list several collections of Chiloschista "parishii" from Bhutan. We believe that these collections represent one or both of the species described in this paper but we have not been able to confirm this.

Etymology: Named in reference to the known general area of distribution; the Himalayas.

AcKnowledgments. The authors thank the Royal Government of Bhutan, the Ministry of Works and Human Settlements, and the Ministry of Agriculture and Forests for providing administrative support. We thank the Department of Forest and Park Services for providing permits to visit and collect orchids in the Protected Areas, and also for providing assistance in the field, such as lodging and field staffs. The authors also thank Tashi Y. Dorji, Program 
Director of the NBC, for her guidance and support. We also thank the accompanying staff of NBC and Thomas Höijer for excellent companionship in the field. We sincerely thank the Sarasota Orchid Society for continuous financial support, Rudolf Jenny for unfailing support with providing copies from his extensive Bibliorquídia library, and Wesley
Higgins and the anonymous reviewers for improving the manuscript. Finally, we thank Sharon and Russell Stephens of Sarasota, Florida, for contributing travel funds for the third author through Grant \#20201631 from the Friends of Orchid Research Fund, administrated by the Community Foundation of Sarasota County.

\section{LITERATURE CITED}

Bentham, G. \& J. D. Hooker (1883). Sarcochilus. In: G. Bentham \& J. D. Hooker, Genera plantarum :ad exemplaria imprimis in Herberiis Kewensibus servata definita, vol. 3, part 2 (pp. 575. L. Reeve \& Co., London, UK.

Blatter, E. \& McCann, C. (1932). Revision of the flora of the Bombay Presidency. Journal of the Bombay natural history society, $35(3), 488$.

Chen, X. \& Wood, J. (2009). Orchidaceae. In: C.Y. Wu, P. H. Raven \& D.Y. Hong (eds.), Flora of China, volume 25 (pp. 470-471). St. Louis: Missouri Botanical Garden Press.

Chowdhery, H. J. (1998). Orchid flora of Arunachal Pradesh. India: Bishen Singh Mahendra Pal Singh.

Chowdhery, H. J. \& Pal, G. D. (2008). Orchidaceae of Arunachal Pradesh (check list). India: Bishen Singh Mahendra Pal Singh.

Don, D. (1825). Epidendrum usneoides. Prodromus Florae Nepalensis: 37. London. UK: Veneunt apud J. Gale, Bruton Street.

Dorji, S. (2008). The field guide to the orchids of Bhutan. Bhutan: Bhutan Orchid Science Society.

Govaerts, R. (2020). Chiloschista. World checklist of selected plant families: Royal Botanic Gardens, Kew. UK. Retrieved from http://wcsp.science.kew.org [accessed Jan. 2020].

Gurung, D. B. (2006). An illustrated guide to the orchids of Bhutan. Thimphu, Bhutan: DSB Publication, GPO Box 435.

Gyeltshen, C., Dalström, S., Gyeltshen, N \& Tobgay, K. (2019). A new spotted Chiloschista (Orchidaceae: Aeridinae) from Bhutan. Lankesteriana, 19(1), 23-29.

Hegde, S. N. (1984). Orchids of Arunachal Pradesh. Arunachal Pradesh, Itanagar, India: Forest department.

Hooker, J. D. (1889). Sarcochilus luniferus. Curtis's Botanical Magazine, 115, t 7044.

King, G. \& Pantling, R. (1898). The orchids of the Sikkim-Himalaya. Annals of the Royal Botanic Garden, Calcutta, 8 , pl. 276.

Lindley, J. (1832). Chiloschista. Edwards's Botanical Register, 18, t. 1522.

Pearce, N. R. \& Cribb, P. J. (2002). Flora of Bhutan, Volume 3, Part 3: The orchids of Bhutan. Edinburgh: Royal Botanic Garden Edinburgh, in collaboration with the Royal Government of Bhutan.

Reichenbach, H. G. fil. (1863). Sarcochilus usneoides. In: W.G.Walpers (ed.), Annales botanices systematicae, tomus VI (pp. 497-498). Londres: C. F. Hofmeister.

Reichenbach, H. G. fil. (1867). Thrixspermum usneoides. Xenia Orchidacea, Beiträge zur Kenntniss der Orchideen. Leipzig: F. A Brockhaus.

Reichenbach, H. G. fil. (1868). Thrixspermum luniferum. Gardeners Chronicle, 3, 768.

Santapau, H. \& Kapadia, Z. (1962). Critical notes on the Orchidaceae of Bombay State. Journal of the Bombay Natural History Society, 59(2), 402.

Schlechter, R. (1919). Chiloschista javanica. Repertorium Specierum Novarum Regni Vegetabilis, Beihefte, 4(95), 275.

Seidenfaden, G. (1988). Chiloschista Lindl. Orchid Genera in Thailand 14. Fifty-nine vandoid Genera. Opera botanica, $95,168-181$.

Smith, J. J. (1905). Die orchideen von Java. In. J. J. Smith (ed.), Flore de Buitgenzorg, series 6 (p. 553). Leiden, Netherlands: E. J. Brill.

Wood, J. (2014). Chiloschista. In: A. M. Pridgeon, P. J. Cribb, M. W. Chase, \& F. N. Rasmussen (eds.), Genera Orchidacearum, volume 6, Epidendroideae (Part 3) (pp. 152-156). Oxford: Oxford University Press.

Zou, L. H., Huang, J. X., Zhang, G. Q., Liu, Z. J. \& Zhuang, X. Y. (2015). A molecular phylogeny of Aeridinae (Orchidaceae: Epidendroideae) inferred from multiple nuclear and chloroplast regions. Molecular Phylogenetics and Evolution, 85, $247-254$ 
LANKESTERIANA 